\title{
THE EARLY PROTEROZOIC SAARI-KIEKKI GREENSTONE BELT: A REPRESENTATIVE OF THE SARIOLA GROUP AT KUHMO, EASTERN FINLAND
}

\author{
ERKKI J. LUUKKONEN
}

LUUKKONEN, ERKKI J., 1989: The early Proterozoic Saari-Kiekki greenstone belt: A representative of the Sariola Group at Kuhmo, Eastern Finland. Bull. Geol. Soc. Finland 61, Part 2, 161-187.

The early Proterozoic Saari-Kiekki greenstone belt in Kuhmo, eastern Finland, is the deformed remnant of a NW-SE-trending elongate structural basin c. $15 \mathrm{~km}$ long and up to $3 \mathrm{~km}$ wide. It is correlated with the Sariola Group in eastern and northeastern Finland as well as with the Sumi-Sariola Group in Soviet Karelia, and is thus one representative of this oldest unit of the Karelia Supergroup preserved in Central Finland.

The volcano-sedimentary sequence of the belt was deposited in terrestial to fluvial environments on late Archaean granitoids and migmatites, in a fault-bounded basin. The basin-margin faults belong to a regional system of dextral strike-slip faults, which were active both prior to (= late Archaean time), during and after the basin formation ( = early Proterozoic time). Locally the marginal zones of the basin are characterized by tectonic-eluvial granitoid breccia hundreds of metres thick, which contain some arkosic layers (= Latvalampi Formation). Subaereal or partly subaqueous basalts, basaltic andesites and andesites were deposited longitudinally in the centre of the basin (= Kaita-Kiekki Formation). In many places the volcanic suite is overlain by the sublitharenites, arkosic sandstones-conglomerates and polymictic conglomerates (= Pötsölampi Formation). The whole belt is cut by NW-SE or NNW-SSE-trending early Proterozoic metadiabase dykes.

$\mathrm{U}-\mathrm{Pb}$ zircon and titanite isotopic data for the metadiabase dyke indicate that the Saari-Kiekki greenstone belt was deposited before $2209 \pm 11 \mathrm{Ma}$. The problematic calc-alkaline trend of the Kaita-Kiekki intermediate volcanites associated with the intracratonic strike-slip fault system is interpreted to be a consequence of late Archaean crustal contamination of basaltic magma at depth during its uprise.

Regional dextral E-SE-trending strike-slip faulting, overthrusting from west to east, open to tight folding, a strong west plunging lineation and the development of the Saari-Kiekki greenstone belt, record an important stage of early Proterozoic reactivation in the late Archaean basement. The early Proterozoic structural patterns can be divided into three deformational phases and the metamorphism during that time seldom exceeded the lower amphibolite facies.

Key words: greenstone belts, stratigraphy, metavolcanic rocks, metasedimentary rocks, chemical composition, deformation, absolute age, Proterozoic, Sariolian, Saari-Kiekki, Kuhmo, Finland.

Erkki J. Luukkonen: Geological Survey of Finland, P.O. Box 1237, SF-70701 Kuopio, Finland. 


\section{Introduction}

The formations composed of diamictites and unsorted and chemically unweathered conglomerates underlying the early Proterozoic Jatuli formations were first referred to as Sariola by Eskola as early as 1919. In 1941 he revised his Sariola concept by including arkosites and arkosic schists in the upper part of the Sariola stratigraphy, and with his ideas concerning chemical weathering during the Sariolan. Väyrynen (1933, 1954) assumed that the Sariola conglomerates were deposited from chemically unweathered, mechanically eroded material, in a terrain of high relief. As soon as terrain became more level, chemical weathering was prevalent so that in many places, the Sariola conglomerates are seen to be weathered in situ without redeposition. This opinion was also accepted by Eskola in 1963. Ojakangas (1965) interpreted Sariola conglomerates to be fluvial and deposited in an environment where mechanical erosion surpassed the chemical weathering. Pekkarinen (1979) pointed out that the Prejatulian (= Sariolan) breccia-conglomerates were almost coeval with the early Karelian weathering crust and that the oldest arkosic suite was fluvial and deposited under desert-like conditions. During this decade, glaciogenic features have been found in the Sariola Formations of eastern Finland (Marmo and Ojakangas 1983,1984; Marmo 1986) and, in contrast to Eskola's original Sariola definition, volcanic units are also included (Laajoki 1973,1980; Meriläinen 1980; Luukkonen and Lukkarinen 1986; Strand 1988).

In Soviet Karelia many Sariola-type formations have been reported, and the Sariola problem has long debated by Karelian geologists. Previously, according to the prevalent Soviet interpretation the Sumi Group is the oldest part of the sequence, and composed of basaltic, andesitic-basaltic, andesitic-dacitic, and rhyolitic metavolcanics together with quartzites, conglomerates and schists. The sequence is intruded by c. $2450 \mathrm{Ma}$ old layered gabbro-anorthosites, pyroxene granites and quartz-porphyry dykes. In many places the Sumi Group is overlain by conglomerates, arkosic quartzites and tuffitic sandstones of the Sariola Group , correlative with the Finnish Sariola formations (Sokolov and Stenar 1980; Kratz and Mitrofanov 1980). In recent years on the basis of lithostratigraphic correlations the Sumi-Sariola in Soviet Karelia has been classified into several stratotypes (Kulikov and Golubev 1984).

a) Seletsky-stratotype considered to resemble the Sariola described by Eskola (1941).

b) Kumsa-stratotype typically consisting of thick basaltic and andesitic-basaltic lava flows alternating in the upper part with mixed volcanogenic sedimentary rocks.

c) Paanajärvi-stratotype having much in common with the Seletsky and the Kumsa-stratotypes, but containing in addition felsic potassium-rich volcanic rocks.

This paper presents the results of recent mapping and structural, lithogeochemical and isotopic studies of the well preserved though metamorphosed Sariolan volcanic and sedimentary succession in the Saari-Kiekki greenstone belt, which was previously poorly known because of its remote location near the Soviet border in eastern Kuhmo. The area had however, been mapped earlier by Wilkman (1900-1909), and the SaariKiekki metabasites and metaconglomerates are mentioned in the explanation to the geological map of Nurmes map sheet area (Wilkman 1921), but not in the sense of belonging to the Sariola Group.

\section{General geology}

The stratigraphic and structural interpretation of the Saari-Kiekki greenstone belt is hindered by the virtual absence of good outcrops in the NW central part of the studied area, and the mylonitic contacts between the formations. The lithological, lithostratigraphical and structural figures (Figs 1, 6, 25) presented here should therefore be considered in this light. 


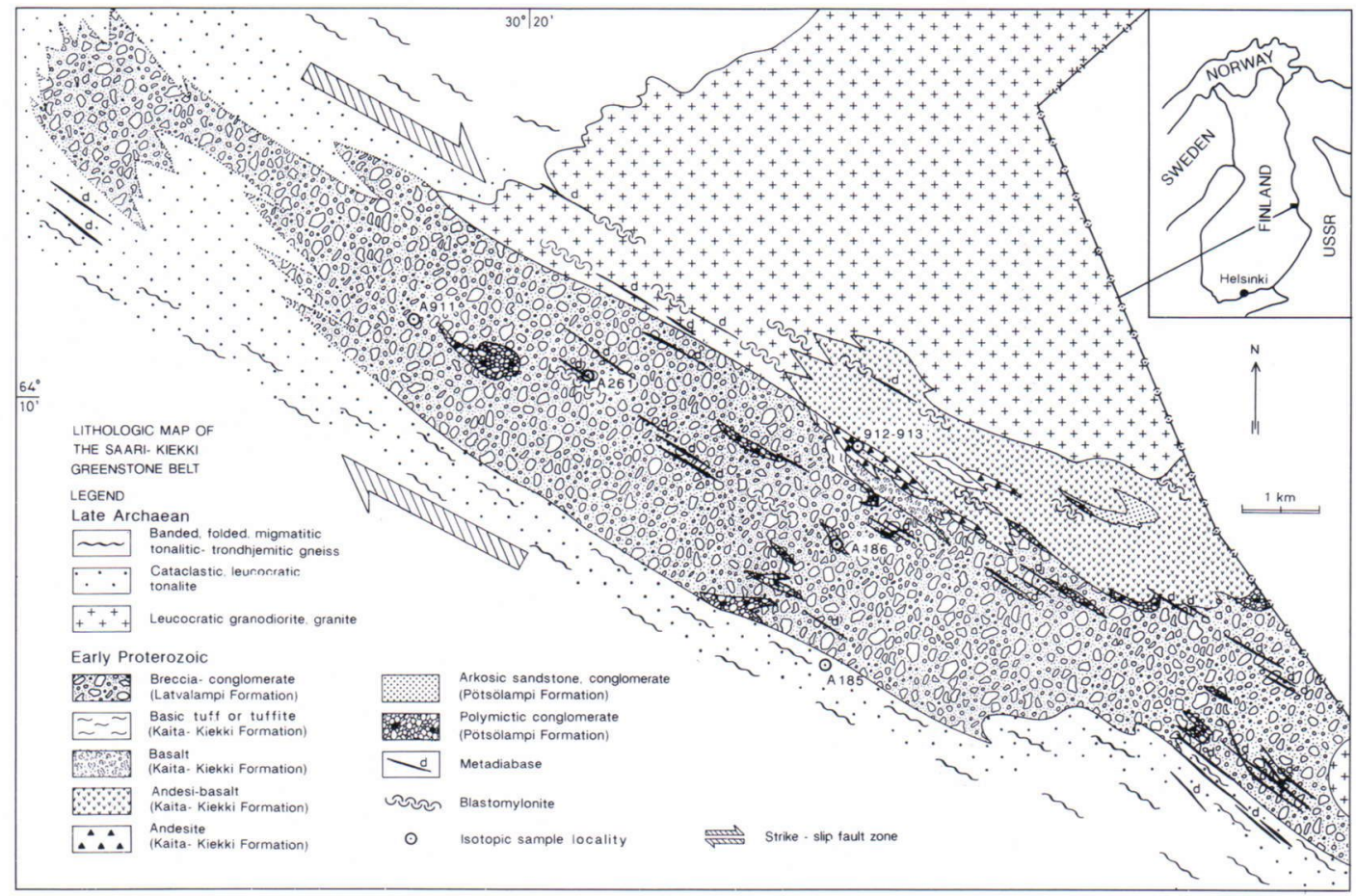

Fig. 1. Simplified map showing the distribution of lithologies in the Saari-Kiekki greenstone belt.

In the area studied the supracrustal rocks are preserved in a southeast-trending synclinorium having faulted margins (Fig. 1). It borders against the Soviet Union, but the extent to which it continues into Soviet Karelia is unknown. In Finland

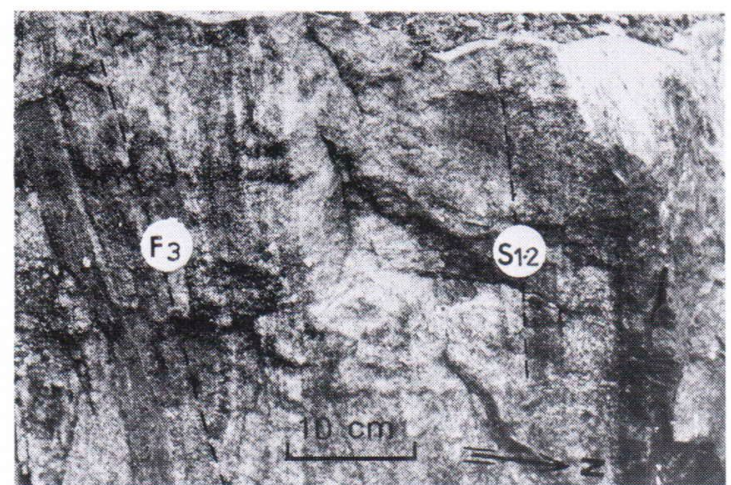

Fig. 2. Banded, folded tonalite-trondhjemite, showing composite foliation $\mathrm{S}_{1-2}$, banding caused by late Archaean metamorphic $\left(\mathrm{M}_{1-2}\right)$ segregation, and almost isoclinal $\mathrm{F}_{3}$ folding. the belt is c. $15 \mathrm{~km}$ long and some $3 \mathrm{~km}$ wide.

The late Archaean basement complex to the south of the greenstone belt consists of late Archaean polydeformed, migmatitic tonalitestrondhjemites (Fig. 2), which towards the mar-

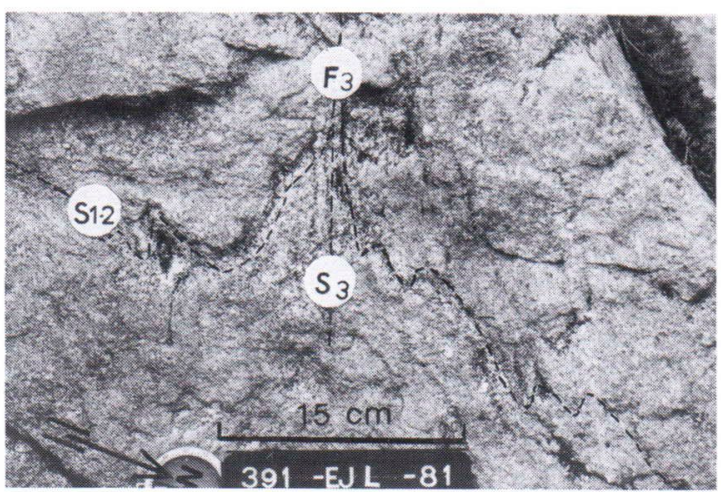

Fig. 3. Cataclastic, leucocratic tonalite with xenolith of totally recrystallized late Archaean banded tonalite-trondhjemite showing late Archaean $\mathrm{F}_{3}$ chevron type folding with $\mathrm{S}_{3}$ axial planar foliation. 
gin of the belt, grade into foliated, cataclastic leucocratic tonalite containing migmatitic tonalitetrondhjemite enclaves (Fig. 3).

Zircon grains from the leucocratic tonalite are rather long (elongation ratios of 5:1 or more), clear and vary from anhedral to subhedral in shape. The $\mathrm{U}-\mathrm{Pb}$ data for four zircon fractions (Table 2, sample A185) from this rock type define a chord which gives an upper intercept with the concordia at $2784 \pm 4 \mathrm{Ma}$, and a lower intercept at $957 \pm 17 \mathrm{Ma}$ (Fig. 4). This age is interpreted as the time of the segregation of this leucocratic material from the older tonalitetrondhjemite (cf. Luukkonen 1988a). This age also indicates that the early Proterozoic overprinting and reheating in the migmatitic tonalites, even in close proximity to the greenstone belt, have not been thorough. The lower intercept age has no apparent relationship to any geological event, but is high enough to indicate a later metamorphism.

To the north of the belt occurs cataclastic porphyritic-porphyroclastic leucocratic granodiorite, the typical predominant igneous component of the late Archaean gneisses in eastern Finland (Hyppönen 1983; Luukkonen 1985,1988b). The contacts between the Saari-Kiekki greenstone belt and the late Archaean basement are not exposed,

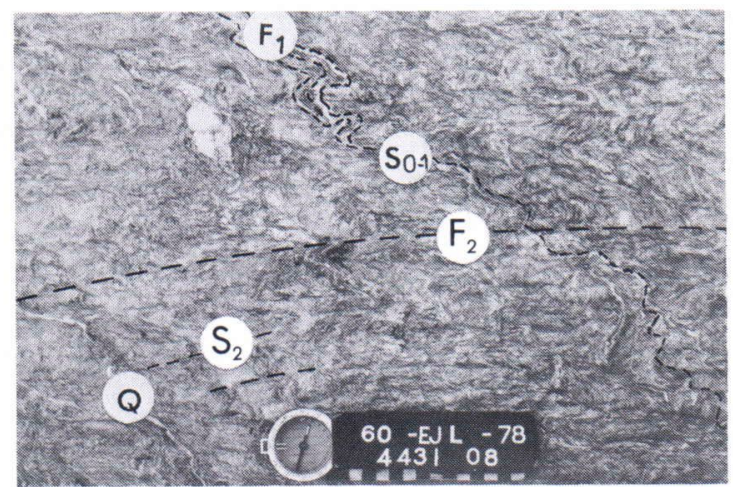

Fig. 5. Blastomylonitic basic volcanite (perhaps tuff/tuffite) showing early Proterozoic $\mathrm{S}_{0}$, tight isoclinal $\mathrm{F}_{1}$ folding with $\mathrm{S}_{1}$ foliation, $\mathrm{S}_{0-1}$ composite foliation, $\mathrm{F}_{2}$ overturned and chevron type folding with axial planar $\mathrm{S}_{2}$ crenulation. Early $F_{1}$ »blind quartz» veins $(Q)$.

but on the basis of the ultramylonites observed along the margins, they are deduced to be tectonic in character (Fig. 5). The total thickness of the greenstone belt is c. $2000-3000 \mathrm{~m}$, and three formations have been distinguished within it. From bottom to top these are (Fig. 6):

a) the Latvalampi Formation, some $500 \mathrm{~m}$ thick, characterized by breccia-conglomerates with arkosic layers in its upper part. This formation occurs principally in the western and southern marginal zone of the belt.

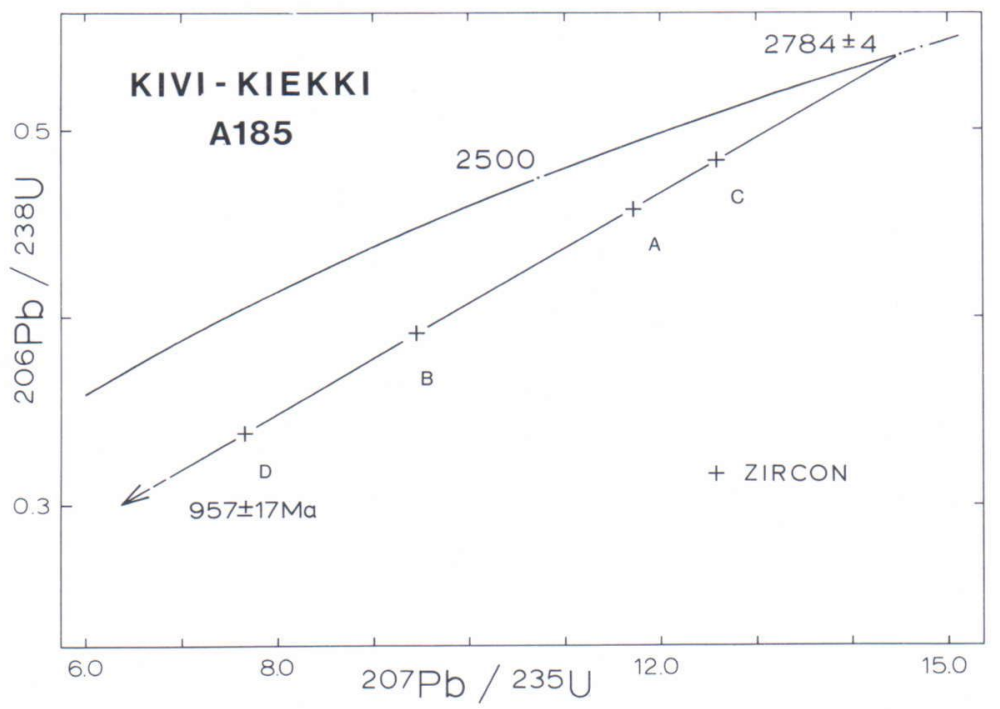

Fig. 4. U-Pb concordia diagram showing data for leucocratic tonalite from near the marginal zone of the SaariKiekki greenstone belt. A chord through 4 zircon fractions has an upper intercept at $2784 \pm 4 \mathrm{Ma}$ and a lower intercept at $957 \pm 17 \mathrm{Ma}$. 
Fig. 6. Simplified diagrammatic stratigraphy of the Sariola in the SaariKiekki greenstone belt.

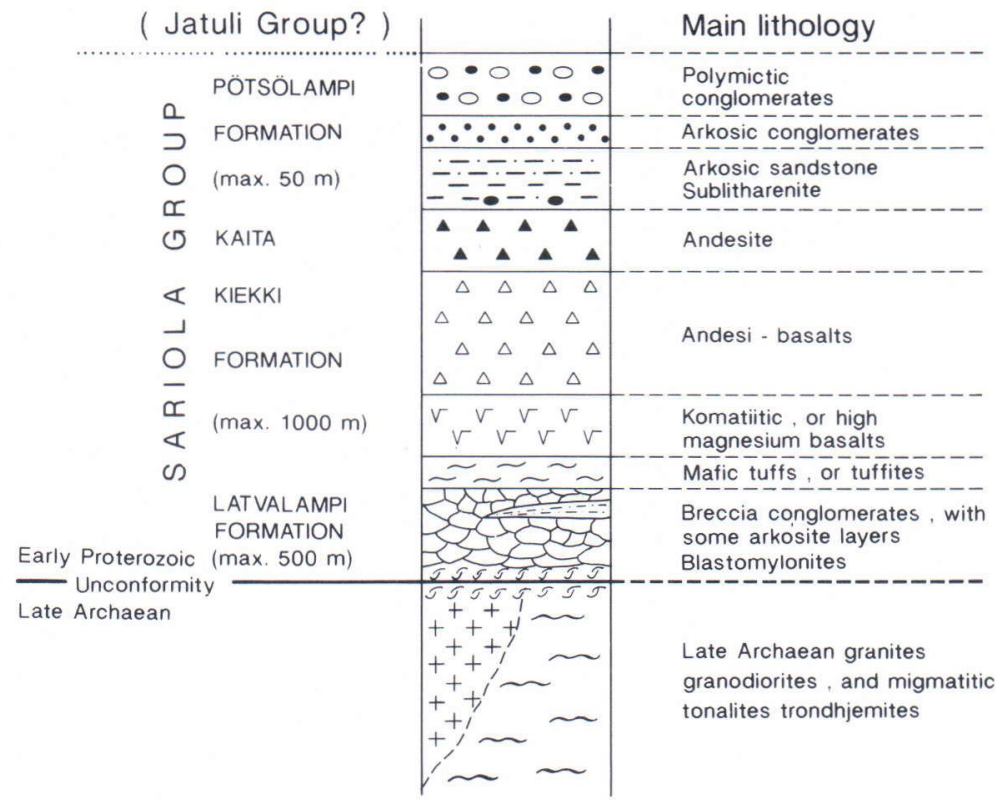

b) the Kaita-Kiekki Formation about $1000 \mathrm{~m}$ thick and largely composed of basalts, basaltic andesites and/or andesites, which compositionally correspond to komatiites and high magnesium tholeiites, although the indermediate volcanites are calc-alkalic. Structures typical of extrusive rocks are seen in this unit, including varioles, amygdales, agglomerates, breccias and tuffites. The Formation is most extensively developed in the middle and eastern part of the belt.

c) The uppermost unit, the Pötsölampi Formation, is composed of sublitharenites, arkosic sandstones-conglomerates and polymictic conglomerates. The unit varies in thickness from several to tens of metres, and frequently occurs as lenticular, sporadic, isolated formations due to tectonic overthrusting.

All the volcanic and sedimentary rocks described below, have undergone polyphase deformation and low-grade metamorphism. Nevertheless, original volcanic and sedimentary structures are commonly well preserved.

\section{Lithology and age determinations}

Although all units in the igneous and sedimentary sequence are metamorphosed, igneous and sedimentary rock names will be used in this paper without the prefix meta.

\section{The Latvalampi Formation}

The sedimentary (commonly cataclastic) rocks of the Latvalampi Formation are characterized by the predominance of heterogeneous conglomerate which, due to as angular fragments (Fig. 7) and lack of internal structures is referred as breccia-conglomerate. It is thickest in the western part of the belt, the total thickness being there c. $500 \mathrm{~m}$, and it rests on the late Archaean basement leucotonalites. Near the contacts the formation is cataclastic and mylonitic.

The breccia-conglomerate contains angular, rarely rounded fragments that are representative of the nearby late Archaean basement such as leucotonalite, migmatitic tonalite-trondhjemite, porphyroblastic granodiorite and banded am- 


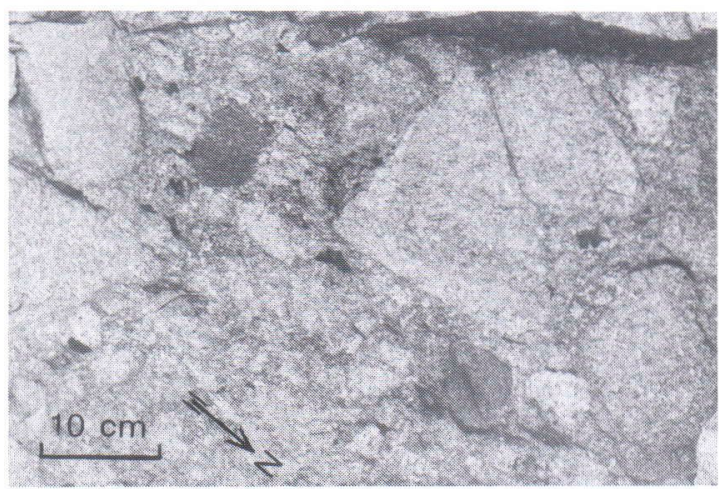

Fig. 7. Clast-supported conglomerate of the Latvalampi Formation.

phibolite, with very little matrix between them. The fragments vary in size from a few tens of centimetres down to granitoid gravel several millimetres in diameter. The granitoid fragments are well preserved whereas the amphibolite ones have completely altered into chlorite or biotite schist. The matrix is an aggregate of sand-sized granitoid clasts, quartz, plagioclase, sericite, biotite, epidote, carbonate and potassium feldspar. The angularity of fragments and the dearth of matrix show that material were transported for only a very short distance.

The zircon population from one angular granodioritic fragment is clear and has an almost euhedral morphology. Four zircon fractions (Table 2, sample A911) from it gives an upper intercept age of $2702 \pm 30 \mathrm{Ma}$ (Fig. 8). This age is coeval with the ages of the most prominent late Archaean $\mathrm{D}_{3}$ granitoid intrusions reported from Kuhmo and Suomussalmi area (cf. Hyppönen 1983; Luukkonen 1988b). The lower intercept with the concordia is $808 \pm 63 \mathrm{Ma}$ (Fig. 8), again indicating some later metamorphic event.

In the uppermost part of the Latvalampi Formation there are pinkish, arkosic layers several metres thick which lack primary sedimentary structures. Narrow arkosic »pockets» in the breccia-conglomerate are interpreted to be allochthonous as a result of overthrusting. The material for the arkosic layers is not so local as in the breccia-conglomerate, but it may be from the reworked and weathered late Archaean basement, or in part derived from a chemically altered breccia-conglomerate.

The immature character of the Latvalampi Formation, with material derived from the local basement granitoids, suggests that mechanical erosion dominated over chemical weathering during that time. The Latvalampi breccia-conglomerate probably primarily represents high relief »talus-slope» deposits, implying fault activity,

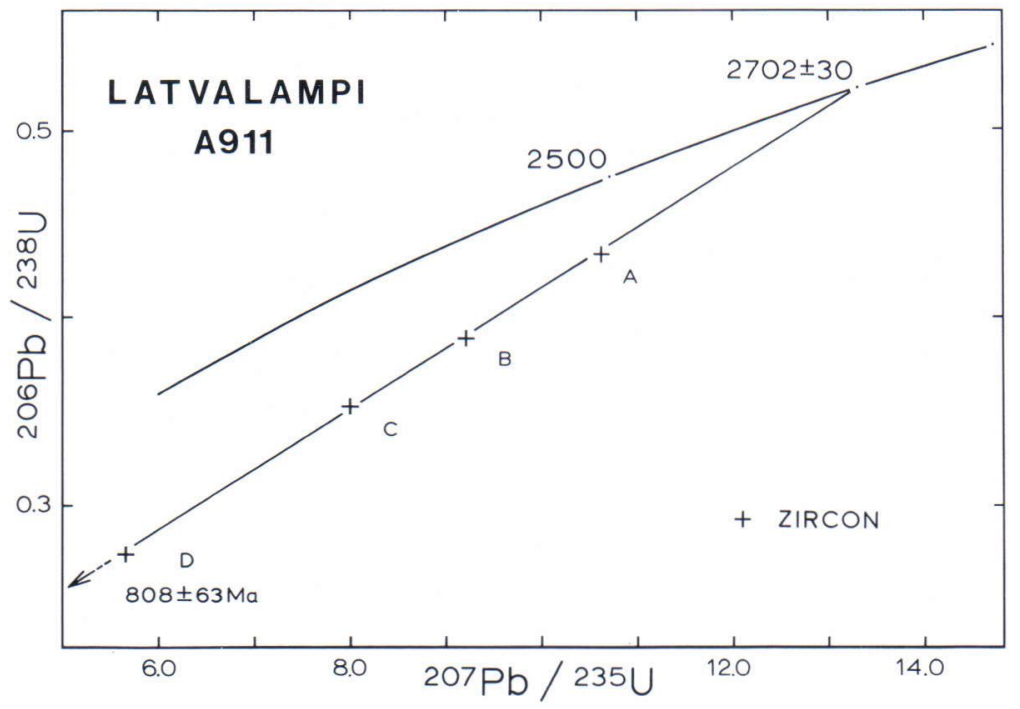

Fig. 8. U-Pb concordia diagram showing data from a granodioritic fragment in the breccia conglomerate of the Latvalampi Formation. A chord through 4 zircon fractions has an upper intercept at $2702 \pm 30 \mathrm{Ma}$ and a lower intercept at $808 \pm 63 \mathrm{Ma}$. 
where joints and fractures developed in reactivated late Archaean zone of weakness, and promoted mechanical erosion in that rock material. The disaggregated rock material remained in situ, or was transported into topographic lows by solifluxion processes. The presence of arkose "pockets" in the upper part of the formation is evidence of fluvially-reworked, more chemically weathered material in this unit (cf. Miall 1978).

\section{The Kaita-Kiekki Formation}

The tuffs or tuffites, and agglomeratic, amygdaloidal, variolitic, massive or brecciated lavas of the Kaita-Kiekki Formation are basic to intermediate in composition (Figs 1,6). In the middle part of the belt, the lowermost unit varies in thickness from a few metres to tens of metres and consists of basic tuffs or tuffites, which are typically cataclastic, dark green, medium to fine grained, and frequently banded (Fig. 9). They contain tremolite-actinolite, chlorite, albite and biotite as the main minerals with carbonate, quartz, epidote, opaque minerals and zircon as accessories. The albite, chlorite and tremoliteactinolite form narrow bands $(0.5-2.0 \mathrm{~mm}$ thick), while a younger generation of tremoliteactinolite forms large porphyroblasts up to 2.0 $\mathrm{mm}$ long parallel to the prevailing $\mathrm{S}_{2}$ crenulation. Some elliptical albite, quartz-epidote aggregates in tuff/tuffite layers are suggestive of a primary, indistinct lapilli texture (Fig. 9). Thicker bands and/or layering $(10-20 \mathrm{~cm}$ thick) are due to the varying amount of biotite and tremolite in the darker bands. In more cataclastic, NW-SE-trending zones the rock is chloriteor quartz-rich and blastomylonites even occur in some places (Fig. 5).

Layered, variolitic, brecciated and massive lavas of komatiitic-high magnesium tholeiitic composition are associated with the unit mentioned above. Major minerals are light coloured amphibole (tremolite-actinolite), chlorite and plagioclase (albite-oligoclase) with accessories including quartz, biotite, epidote, carbonate,

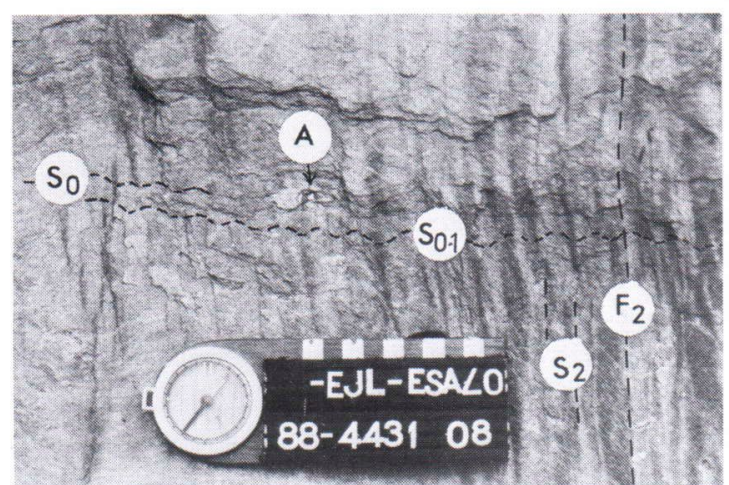

Fig. 9. Banded basic tuff/tuffite of the Kaita-Kiekki Formation showing layering $\mathrm{S}_{0}$, a composite foliation $\mathrm{S}_{0-1}, \mathrm{~F}_{2}$ chevron-kink type folding with axial planar foliation $\mathrm{S}_{2}$. (A) = indistinct intermediate lapilli in mafic tuff/tuffite.

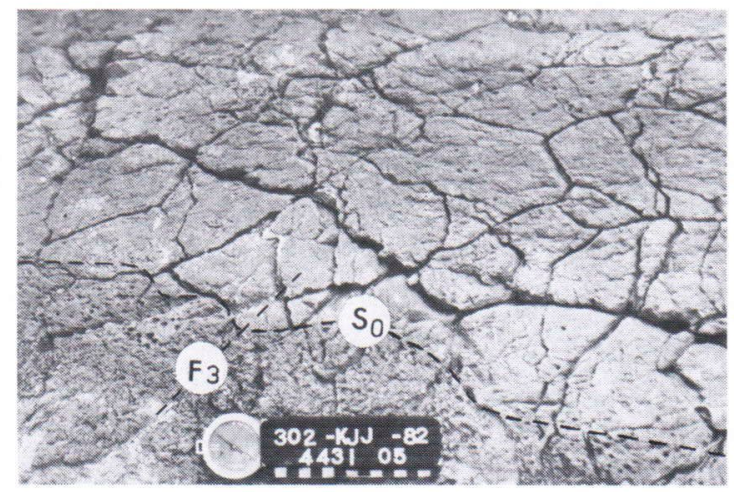

Fig. 10. Brecciated komatiitic-high magnesium basalt of the Kaita-Kiekki Formation showing layering $\left(\mathrm{S}_{\mathrm{o}}\right)$, dextral $\mathrm{F}_{3}$ folding, and variolitic structure towards the top of the basaltic lava layer.

opaque and titanite. The original texture has generally been destroyed due to the recrystallization, and plagioclase, for example, is usually recrystallized to a granoblastic mosaic. The variolitic, brecciated structures and layering are very well seen in cross-section perpendicular to the prevailing $\mathrm{S}_{2}$ foliation (Fig. 10). The variolitic structure is common in the upper part of each layer and a typical feature for this lava unit. The varioles are $1-9 \mathrm{~mm}$ in size, elongated in the direction of the main lineation $\left(\mathrm{L}_{2}\right)$, and they are composed mainly of granoblastic plagioclase 
and quartz, with varying amounts of tremolite and epidote.

The bulk of the Kaita-Kiekki Formation is composed of amygdaloidal, brecciated, almost totally ecrystallized basaltic andesite flows, with a few interlayers of andesites that may in fact be tectonic slices. The major minerals are hornblende (or tremolite-actinolite), plagioclase (albite-oligoclase) and quartz. Biotite is present in minor amounts in NW-SE-trending cataclastic zones. Chlorite, opaque minerals, epidote, titanite and zircon are accessory minerals. The original volcanic texture has generally been destroyed with plagioclase and quartz recrystallized to granoblastic mosaic. The amygdules $(0.5-3.0$ $\mathrm{mm}$ in size) are filled with quartz, tremolite and albite and in some places with biotite, and surrounded by a fine grained quartz - plagioclasetremolite rim. Some of the globular, variolitic textures (1-12 $\mathrm{mm}$ in size) in numerous basaltic andesite layers are interpreted to be the result of spherulitic crystallization (Fowler et al. 1987). Varioles are composed of a granoblastic quartz -plagioclase mass, with additional variable amounts of colourless tremolite, epidote and opaque. Radiating crystals of plagioclase, or pyroxene are no longer seen and the present felsic composition of the varioles merely reflects the albitization of the former Ca-rich plagioclase. The polygonal jointed lava layer, in the inner part of the Formation, formed as a consequence of thermal contraction as the lava flow cooled (Fig. 11). The joints, with light coloured rims, separate angular units from a few centimetres to a few tens of centimetres. In this lava unit, indistinct brecciated, variolitic pillow lava has been found on the northern shore of Kaita-Kiekki lake reflecting a probable subaqueous volcanic origin. Close to the NW-SE-trending fault zones, the volcanic rocks have subparallel crenulation (or $\mathrm{S}_{2}$ schistosities) and are altered into chlorite schists or chlorite-biotite schists and tectonic breccias associated with penetrative metasomatic processes, mainly albitization. Elsewhere such penetrative deformation is difficult to detect.

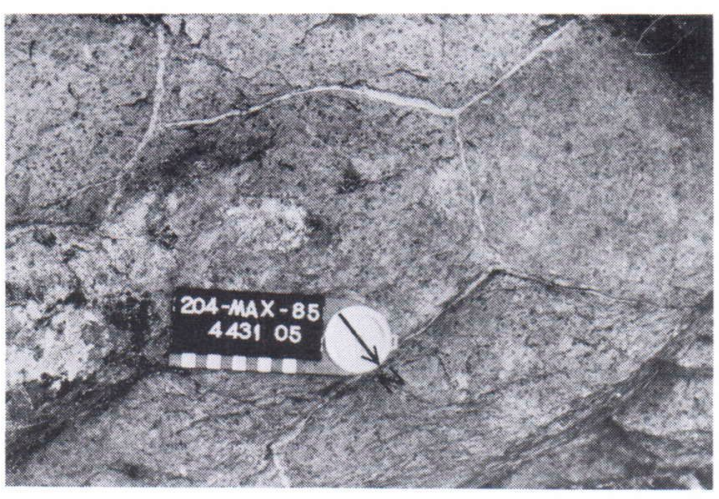

Fig. 11. Pentagonally jointed basaltic andesite of the KaitaKiekki Formation. Figure perpendicular to the prevailing lineation $\left(\mathrm{L}_{2}\right)$.

The uppermost unit of the Kaita-Kiekki Formation contains amygdaloidal, brecciated and agglomeratic andesites. Distinctive and commonly seen features of this unit are round to ovoid, pale globules generally $4-10 \mathrm{~cm}$ in size (Fig. 12) that can be interpreted as the ocellar structure of rapidly cooling immiscible, intermediate and felsic magma (possibly result of crustal contamination cf. p. 174-175). The top of the andesitic layers crystallized rapidly to produce chilled margins, whereas the cooling in the rest of the intermediate magma caused unmixing, producing immiscible droplets of light felsic liquid (ocelli), which rose and coalesced as light globules in more dense, intermediate andesitic lava matrix. The globules are best seen on the outcrops perpendicular to the main lineation $\left(=\mathrm{L}_{2} ;\right.$ Fig. 12) and are now composed of epidote, quartz, albite and colourless amphibole, merely reflecting the albitization and epidotization of the former $\mathrm{Ca}$ rich plagioclase globules. Elsewhere the rock contains varying amounts of quartz, albite, light coloured amphibole and hornblende with accessory epidote, chlorite, biotite, opaque and titanite. The andesites are totally recrystallized, but amygdules, which have also been found in the light globules and agglomeratic structures, are clearly visible. Tectonic breccias associated with the metasomatic albitization, epidotization and 


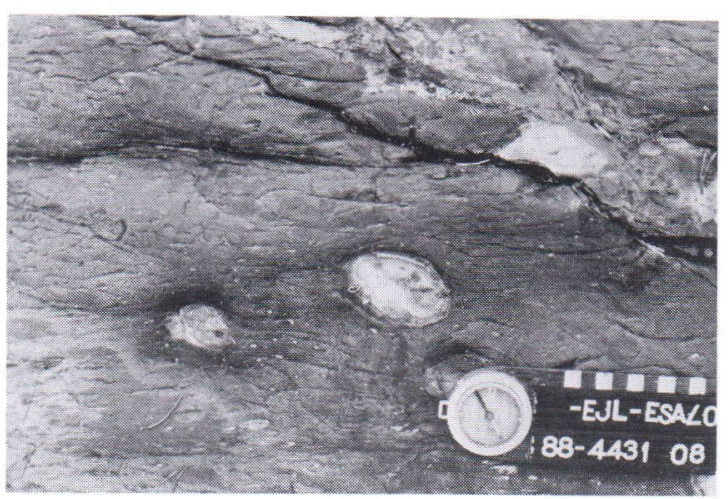

Fig. 12. Andesite lava with elongated pale globules and amygdules of the Kaita-Kiekki Formation. Figure perpendicular to the prevailing lineation $\left(\mathrm{L}_{2}\right)$.

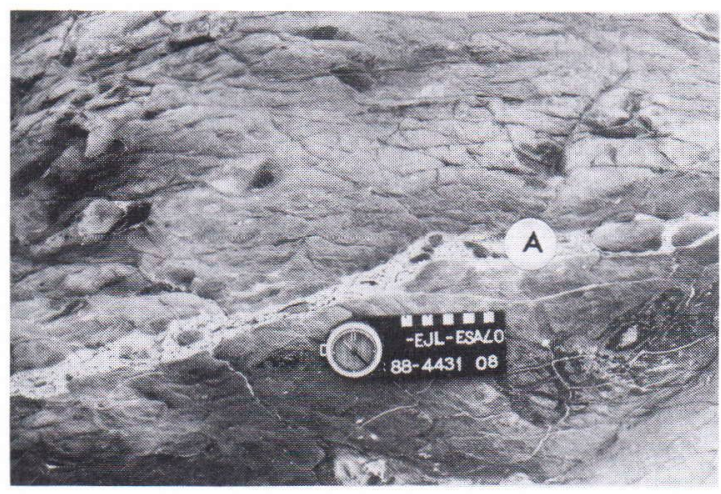

Fig. 13. Polygonal jointed, and NW-SE-trending $\left(\mathrm{F}_{2}\right)$ metasomatically altered fault zone (A) of the Kaita-Kiekki Formation.

biotitization can be seen close to the NW-SEtrending fault zones in several places (Fig. 13).

All the lava flows of the Kaita-Kiekki Formation show mainly subaereal characteristics, such as breccia, amygdaloidal, pale globules, varioles while subaqueous features are seldom visible. The Formation is interpreted to have been erupted under subaereal or even partly shallow water conditions.

\section{The Pötsölampi Formation}

Narrow, tectonically isolated »pockets» of the Pötsölampi Formation form the uppermost unit in the Saari-Kiekki greenstone belt stratigraphy (Figs 1,6). It occurs in the central and southeastern part of the belt, and consists of the sublitharenites, arkosic sandstone-conglomerates and polymictic conglomerates. The maximum observed thickness of the Formation is only a few tens of metres.

In a NW-SE-trending, tectonically isolated basin, near Pötsölampi in the central part of the belt, andesite is overlain by sublitharenite (terminology after Pettijohn 1975) only few metres thick, and composed of approximately 5-10\% subangular, elongated sericite schist fragments, possibly representing of boudinage of discontinuous interbeds of tuffaceous siltstone or claystone in an arkosic sandstone matrix (Fig. 14; the real pelite fragments are met with in nearby glacial erratic boulders). The sublitharenite is overlain by $10-20$ metres of arkosic sandstone and is composed mainly of quartz, albite, potassium feldspar and sericite. The accessories are chlorite, biotite, opaque minerals, zircon and rutile. Despite the cataclastic and pseudoclastic texture, the original outlines of sand-sized grains are in places visible under the microscope, and the roundness of these grains is generally poor. The sublitharenite and the arkosic sandstone can be correlated with the sheetflood facies, the overbank facies more typically consisting of fine sands, with thinly interbedded silts and clays (cf. Hempton et al. 1983).

Arkosic sandstone-conglomerate occurs together with the arkosic sandstone and even where very cataclastic, its texture is very well seen in the outcrops perpendicular to the prevailing lineation (Fig.15). It consists of granitoid and feldspar pebbles ( $1-4 \mathrm{~cm}$ in size) eroded from late Archaean granitoids, and some chlorite schist clasts that come from the greenstone belt itself. The matrix is composed of fine grained quartz, feldspar and sericite. The arkosic sandstone-conglomerate is interpreted as sheetflood facies, consisting of horizontally laminated or massive sheets of pebbly sands (cf. Hempton et al. 1983).

The detrital zircon population in the sub- 


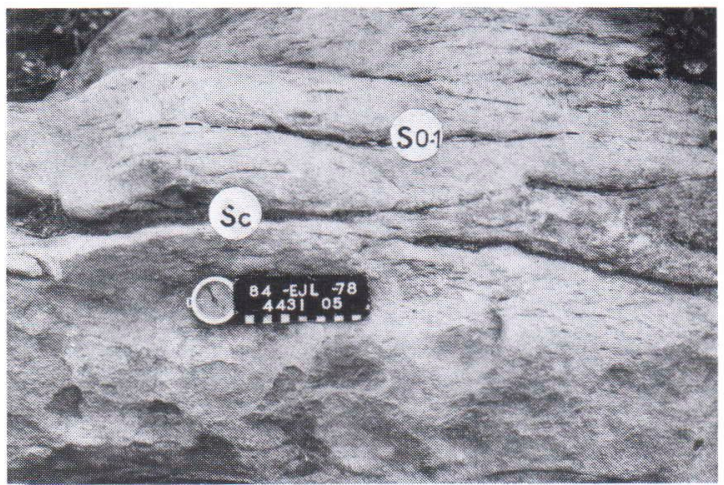

Fig. 14. Sublitharenite with elongated, boudinaged sericite schist (SC) (parallel to $\mathrm{S}_{0-1-2}$ ) layers in the Pötsölampi Formation.

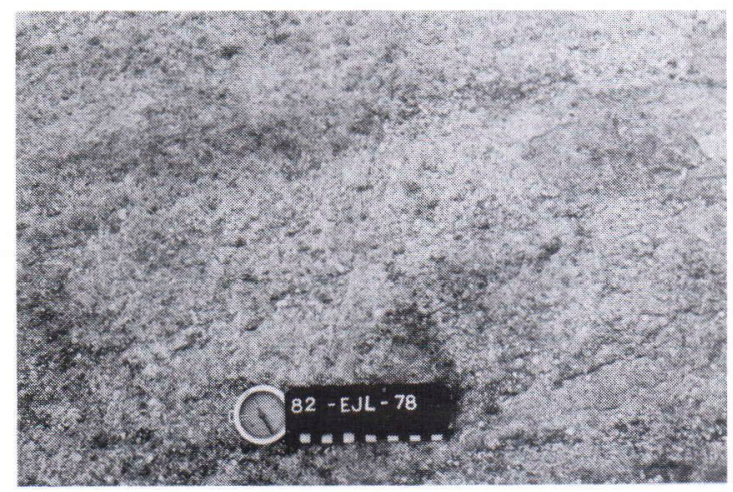

Fig. 15. Arkosic sandstone-conglomerate of the Pötsölampi Formation. litharenites and arkosic sandstone-conglomerate is dominated by fine grained, yellowish and subrounded grains. Ten analyzed fractions (four of which were cleaned by abrasion) form an array (Table 2, samble A912, 913) with an upper intercept on the concordia at $2686 \pm 66 \mathrm{Ma}$ and the lower intercept at $238 \pm 118 \mathrm{Ma}$ (Fig. 16). This age (within error limits) and the composition of pebbles in the arkosic conglomerate indicate that the main detrital source of the material was the late Archaean $\mathrm{D}_{3}$ granitoids.

The uppermost suite, coeval with the sublitharenite and arkosic sandstone-conglomerate in the Pötsölampi Formation is commonly a cobble and boulder dominated, volcaniclastic, polymictic conglomerate and a matrix-supported conglomerate has also been found near the Soviet border. The granitoid clasts are more rounded than the clasts of the breccia conglomerates in the Latvalampi Formation. The absence of pyroclastic and lava interbeds indicates that the polymictic conglomerates were deposited after the cessation of volcanism. It occurs as lenticular »pocket»-like allochthonous layers in the greenstone belt, and in the brecciated late Archaean granitoids (Fig. 1). Rounded to subangular boulders, cobbles and pebbles $5-70 \mathrm{~cm}$ in size are of late Archaean granitoids, or volcanic

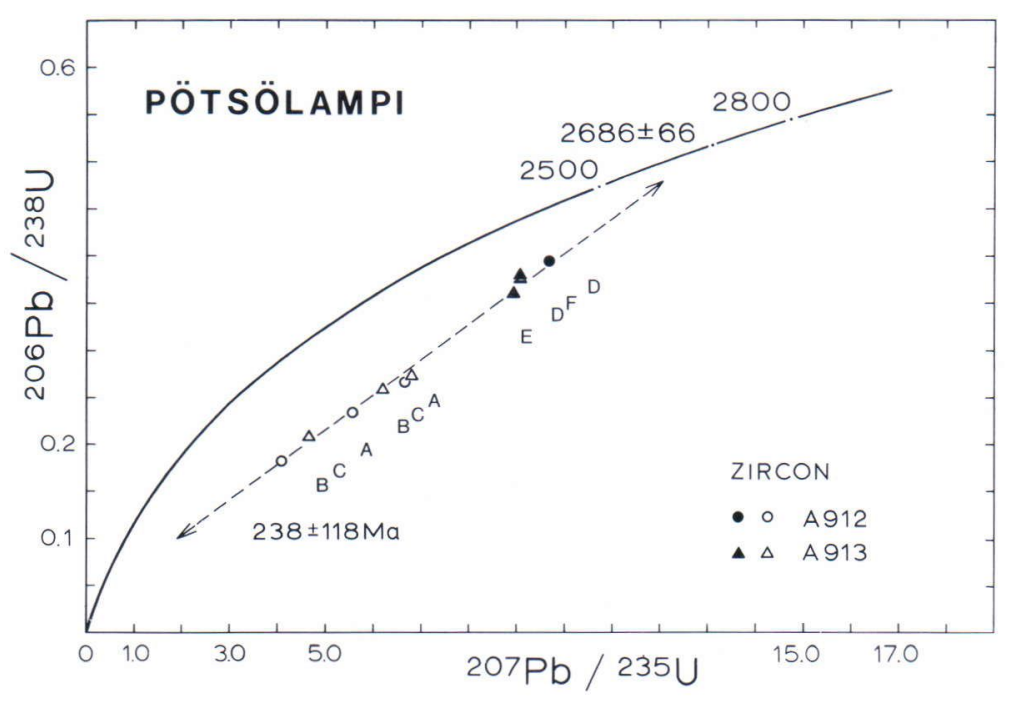

Fig. 16. U-Pb concordia diagram showing data for detrital zircons from sublitharenites and the arkosic sandstone-conglomerate of the Pötsölampi Formation. A chord through 10 zircon fractions has an upper intercept at $2686 \pm 66 \mathrm{Ma}$ and a lower intercept at at $238 \pm 118 \mathrm{Ma}$. Abraded fractions marked with filled circles and triangles. 
lithologies from the lower part of the greenstone belt (Figs 17, 18), and also quartz porphyry pebbles from an unknown source have been found near the Soviet border. The matrix is rich in chlorite and amphibole, and in places granitoid and feldspar gravelly detritus is abundant. The polymictic conglomerate commonly lacks primary internal texture and is poor in matrix. Accordingly it is fluvially-reworked, with clast supported conglomerate being typical deposits in the margins of fault bounded basins (Hempton et al. 1983).

One granitoid boulder of the polymictic conglomerate has been dated. The interpretation of an isotope system consisting of five isotope ratios for zircons from Sample A186 Saari-Kiekki (Table 2), is somewhat unambiguous. The most probable solution is a chord through points A,B,C which has an upper intercept at $2683 \pm 40$ Ma (Fig. 19), being almost coeval (within error limits) with the late Archaean $\mathrm{D}_{3}$ granitoids. All three isotope ratios for titanites lie above the concordia showing an age approximately $1800 \mathrm{Ma}$ (Fig. 19). The corresponding ${ }^{207} \mathrm{~Pb} /{ }^{206} \mathrm{~Pb}$ ages are 1858,1850 and $1794 \mathrm{Ma}$. This result is quite significant, because Proterozoic ages for titanites have not been found in the Archaean formations in Kuhmo-Suomussalmi area, and may indicate

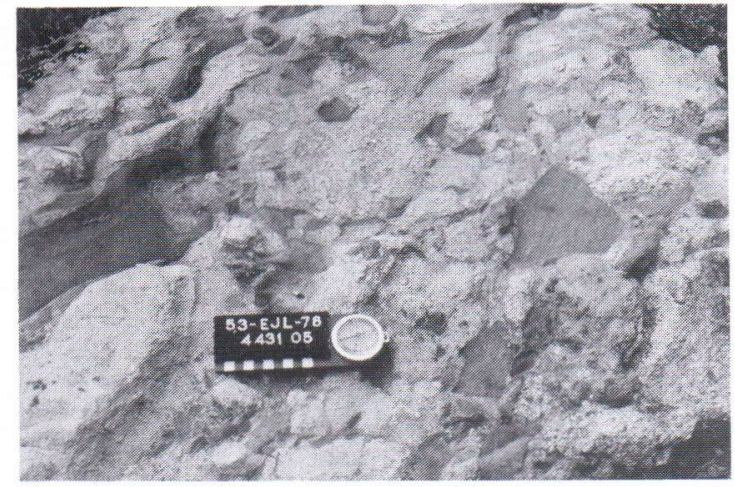

Fig. 17. Granitoid-volcaniclastic clast-supported conglomerate of the Pötsölampi Formation.

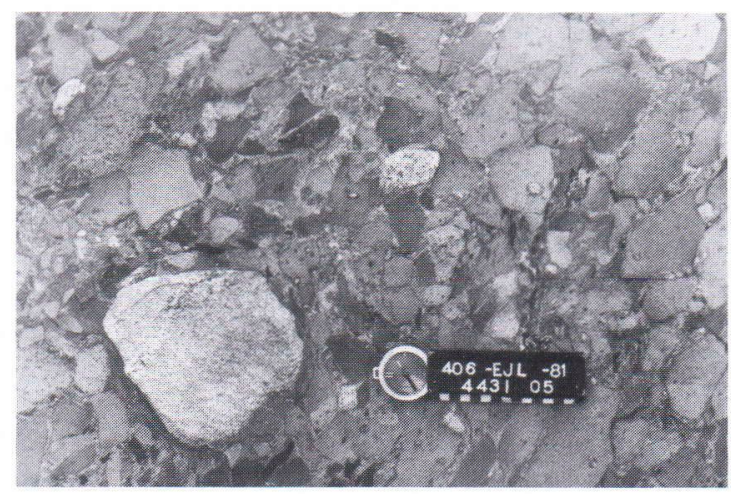

Fig. 18. Volcaniclastic clast-supported conglomerate of the Pötsölampi Formation.
Fig. 19. U-Pb concordia diagram showing data for a granitoid boulder from polymictic conglomerate of the Pötsölampi Formation. A chord through three zircon fractions has an upper intercept at $2683 \pm 40 \mathrm{Ma}$ and a lower intercept at $1249 \pm 31 \mathrm{Ma}$. A chord through three titanite fractions gave an age of c. $1800 \mathrm{Ma}$.

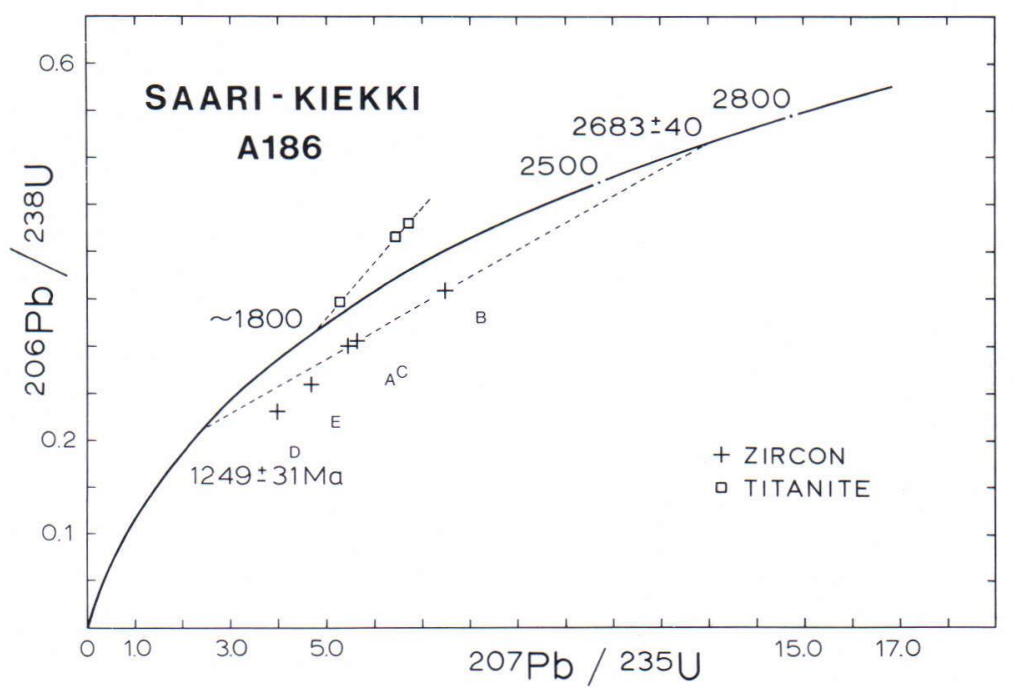


local metamorphic resetting during the Svecofennian orogeny in the Saari-Kiekki greenstone belt.

The pebble population of the arkosic sandstone conglomerates and the cobbles and pebbles in the polymictic conglomerate as well as the composition of the sandstone in the Pötsölampi Formation indicate a mixed provenance of both the Kaita-Kiekki-type volcanic rocks and the late Archaean granitoids. It also provides evidence for recycling of the older Latvalampi Formation into overlying stratigraphic units in the terrigenous sedimentary succession. The major element geochemistry of the sublitharenites and arkosic sandstones-conglomerates show a low to moderate maturity (Table 1). The chemical index of alteration (CIA) of Nesbitt \& Young (1982) ranges from 66.14-68.59 and the major element composition of the sublitharenites and the sandstones, as well as the age determinations from the detrital zircons of the Pötsölampi Formation, suggest that the late Archaean $\mathrm{D}_{3}$ leucotonalites, granodiorites and tonalites dominated in the source area.

\section{Diabase dykes}

Varially undeformed, diabase dykes several tens of metres thick, trending NW or NNW across the Saari-Kiekki greenstone belt and the surrounding late Archaean granitoids are the youngest rocks in the area. Hornblende and andesine are the predominant minerals, but clinopyroxene, orthopyroxene and andesine are the main minerals in the southeast corner of the study area. Leucoxene, magnetite, quartz, biotite, chlorite, titanite and zircon occur in minor proportions. Light coloured, albite-rich, roundish segregations $20-50 \mathrm{~cm}$ in size have been found in the dykes north of the Levävaara hill. Despite recrystallization, the primary ophitic texture is clearly visible as a blasto-ophitic texture in the majority of the dykes studied.

The zircon population of the albite-rich segregations in the Rasiaho diabase dyke (Fig. 1; sample A261) contains three different type of zircons, the majority of which are obscure, redbrown and short. The $3.8-4.0 \mathrm{~g} / \mathrm{cm}^{3}$ fraction includes normal magmatic, euhedral, translucent zircons (found as cores within the prevailing red-brown zircon crystals) and half of the $4.3-4.6 \mathrm{~g} / \mathrm{cm}^{3}$ fraction contains platelike, yellowgreen grains (Table 2, sample A261). However, the U- $\mathrm{Pb}$ data for two titanite fractions (Table 2; sample A261) are more concordant than for the zircon fractions. The proper age $2209 \pm 11 \mathrm{Ma}$ is based on them, being the mean value for both the titanite fractions (fractions $\mathrm{K}$ and $\mathrm{J}$ ), and the limits of error $\pm 11 \mathrm{Ma}$ is the deviation in both directions. This age is interpreted as the time of crystallization of the diabase dykes, which is coeval with the diabase dykes in nearby map sheet areas (cf. Hyppönen 1983). U-Pb data for the translucent zircons (fractions I and L), and for two titanite fractions defines a chord which gives an upper intercept with the concordia at $2224 \pm$ $30 \mathrm{Ma}$, and a lower intercept at $568 \pm 298 \mathrm{Ma}$. This regression is indicated by the dotted line in the concordia diagram of Fig. 20.

\section{Geochemistry and petrogenesis of the volcanites}

The Saari-Kiekki greenstone belt has a low metamorphic grade and the initial designation of different rock types was aided by geochemistry. However, it has been shown that in the NWSE-trending early Proterozoic structural zones, alteration processes such as hydration, carbonatization, albitization, and epidotization, if extensive, will, drastically alter the primary chemical composition of the rock. The best analyses were used in the definiting of three classes; basalts, basaltic andesites and andesites. Classification into the other units of the Formation was based largely on overall field appearance, texture and petrology together with the geochemical characteristics. All the analyses of major and minor elements in this study, given in Table 1, were carried out at the Research Laboratories of Rautaruukki Co. using XRF techniques. 
Fig. 20. U-Pb concordia diagram showing data for the Rasiaho diabase dyke (the albite-rich segregations). A chord through two titanite fractions gives an age of $2209 \pm 11 \mathrm{Ma}$ (= solid line). A chord through two zircon (translucent) and two titanite fractions has an upper intercept at $2224 \pm 30$ Ma and a lower intercept at $568 \pm$ $298 \mathrm{Ma}$ (dotted line).

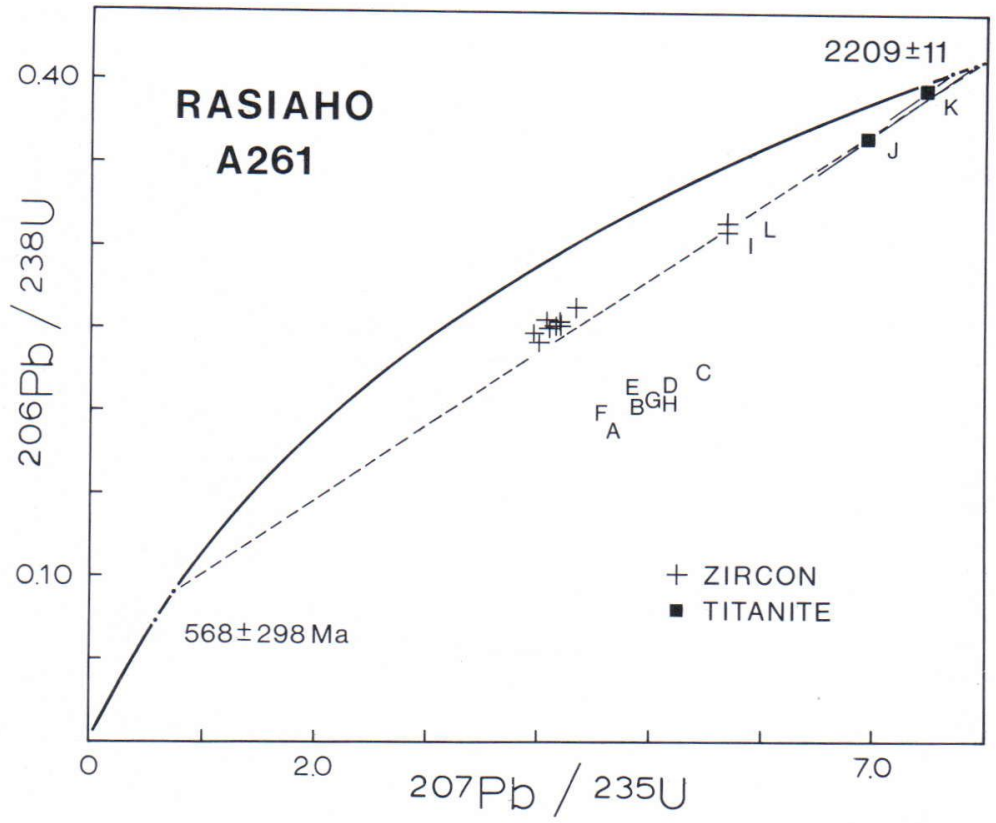

According to the classification of Irvine \& Baragar (1971) the volcanites of the Kaita-Kiekki Formation would be located in the tholeiitic and calc-alkalic fields in the AFM diagram. The great majority of the analyses fall in the calcalkalic field being basaltic andesites and andesites. Only basic tuffs and some of the lowermost basalts in the Kaita-Kiekki Formation are tholeiitic (Fig. 21). All the early Proterozoic diabase analyses form a distinct group in the ironrich tholeiitic field, as do most of the early Proterozoic diabases in nearby map sheet areas (Kilpelä 1990).

The $\mathrm{MgO}-\mathrm{CaO}-\mathrm{Al}_{2} \mathrm{O}_{3}$ diagram shows that the basic volcanites cluster into two groups, the komatiitic-Mg-rich tholeiitic basalts and the normal tholeiitic basalts (Fig. 22). For the komatiitic-high magnesium basalts $\mathrm{MgO}$ contents are 7.55-11.0\%, and $\mathrm{Al}_{2} \mathrm{O}_{3}$ contents 10.30 -13.40 , being thus more aluminium-rich than typical Archaean Barberton-type komatiitic basalts (Viljoen et al. 1982). A very clear compositional break emerges between the two main basaltic groups. MgO content for the latter, the normal tholeiites, is between $3.76-8.67 \%$. The analyses showing the existence of an aluminium-rich trend, are interpreted to be derived from altered rocks, epidotized and albitized basalts, basaltic andesites and andesites.

The compositional break between the two basic volcanite types is also seen on the Jensen (1976) diagram (Fig. 23). On the original Jensen diagram the line separating the tholeiite from the komatiite field transects the other group of basic volcanites. Only the six most basic analyses (from basic tuffs/tuffites and lower basic lava) are real komatiitic basalts, and the remainder being magnesium-rich tholeiitic basalts, or calcalkalic basalts-basaltic andesites. The anomalous high $\mathrm{Al}_{2} \mathrm{O}_{3}$ contents in five basaltic andesites are obtained from the altered, albitized and epidotized rocks, in NW-SE-trending faults. Two analyses of the younger diabases plot in the tholeiite field as in AFM diagram.

In terms of the criteria applied to classify modern orogenic andesites published by Gill (1981), the basaltic andesites and the andesites in the Saari-Kiekki greenstone belt resemble a typical mantle derived, low-potassium, calc-alkalic fractionation trend (Fig. 24). Since the calc-alkalic 


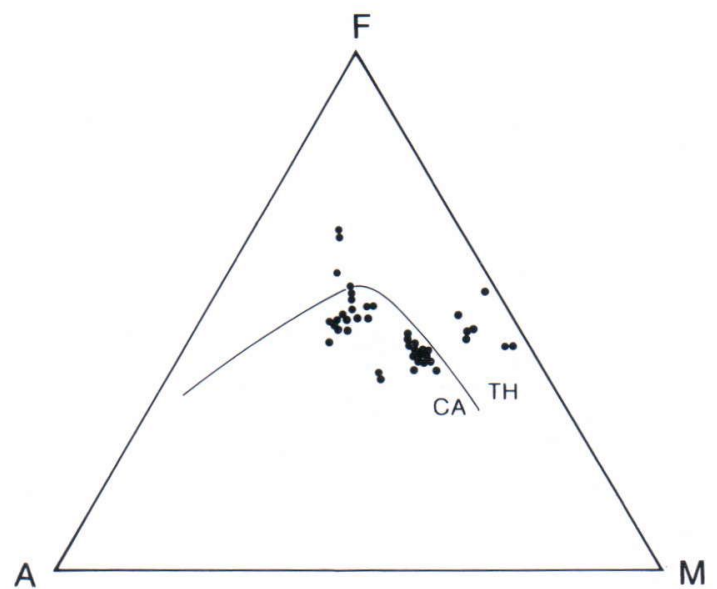

Fig. 21. AFM diagram for volcanites from the Kaita-Kiekki Formation. Heavy solid line separates tholeiitic (TH) from calc-alkaline (CA) suites using the criteria of Irvine and Baragar (1971).

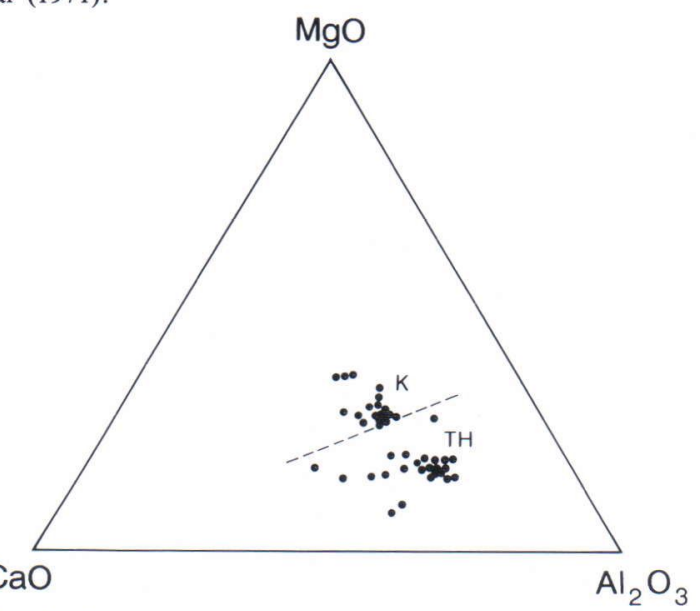

Fig. 22. $\mathrm{CaO}-\mathrm{MgO}-\mathrm{Al}_{2} \mathrm{O}_{3}$ diagram showing compositions of komatiitic (K) and tholeiitic (TH) lavas of Kaita-Kiekki Formation. andesites typically predominate near convergent plate margins, the explanation for the origin of Saari-Kiekki andesites must be exceptional as they are associated with strike-slip faulting in the late Archaean craton. The major-element compositions of continental flood basalts $(=\mathrm{CFB})$ and mafic dykes world wide indicate that very few mantle-derived CFB magmas have reached the surface without pausing and re-equilibrating during their ascent through the crust, particularly in the case of post-Archaean basalts (Thompson et al. 1983; Condie 1985). In the area studied the brecciated late Archaean migmatites and granitoids in the crust could easily have been partially fused during the ascent of hot komatiitichigh magnesian basaltic magma, and crustal contamination is quite plausible. When the komatiitic - high magnesian magmatism was initiated, the crust was cold enough to allow some basalts to penetrate to the surface (= lower basic tuffs/ tuffites and basic lava in the Kaita-Kiekki Formation). Simultaneously basaltic extrusions added heat to the tonalitic (-granodioritic) crust, and partial melting as well as stronger crustal contamination was possible. However, the crust in Saari-Kiekki area evidently did not become sufficiently hot and ductile as to result in the generation of felsic magma. Thus instead of rhyolites and granites, the Saari-Kiekki sequence contains basaltic differentiates and/or hybrid basaltic andesites - andesites (basalt + crust) (cf. Huppert et al. 1984; Huppert and Sparks 1985, 1988). For example if the basalt contained $48 \%$

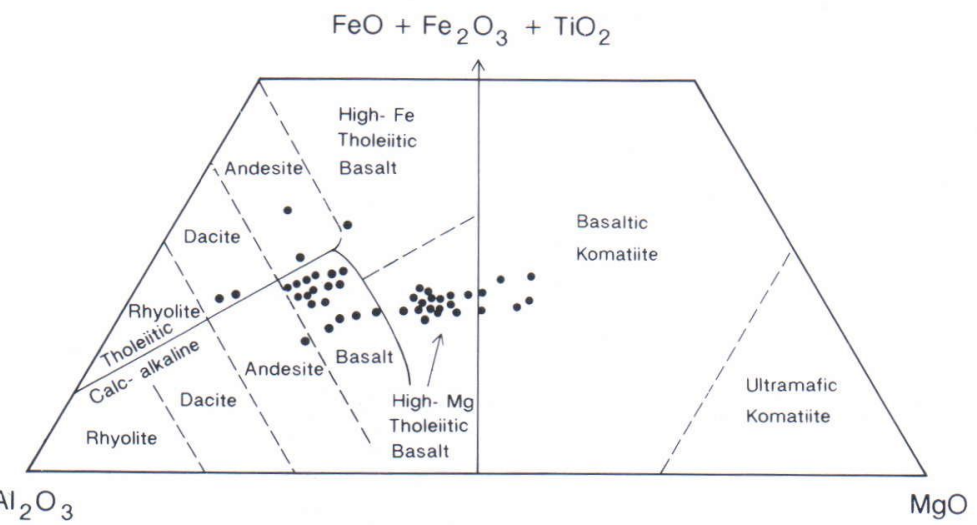

Fig. 23. Jensen cation diagram showing the distribution of volcanic rocks from the Kaita-Kiekki Formation. Fields divited after Jensen (1976). 
$\mathrm{SiO}_{2}$ before contamination it would be basaltic andesite or andesite after contamination by the tonalitic crustal material in the Saari-Kiekki area (cf. Pearce 1983). The crustal contamination of basaltic material at depth during the uprise of magma could explain the high proportion of basaltic andesites and andesites in the KaitaKiekki Formation. According to Huppert and Sparks (1985) thermal erosion during the ascent takes place on both sides of the feeder dyke, and under some circumstances, the amount of crustal contamination may reach $30-40 \%$. The evidence for this kind of phenomenon can be demonstrated by $\mathrm{Zr} / \mathrm{Mg}^{\#}\left(\mathrm{Mg}^{\#}=\mathrm{Mg} /\left(\mathrm{Fe}_{\text {tot }}+\right.\right.$ $\mathrm{Mg}$ )) ratios being above the fractionation trend, and correspondingly $\mathrm{V} / \mathrm{Mg}^{\#}$ ratios being below the fractionation trend (Fig. 25), since $\mathrm{Zr}$ tends to be enriched in continental crust whereas $\mathrm{V}$ is relatively depleted. In the case of volcanites in the Kaita-Kiekki Formation, the parental magma (= lowermost komatiitic basalt) is close to average komatiite in composition. Therefore the data in the Figure 25 possibly indicate the effects of significant custal contamination. However, the absence of REE and isotopic data limit the confidence of this assertion.

\section{Structural history}

In the late Archaean basement away from the Saari-Kiekki greenstone belt, early Proterozoic reactivation has been resolved mainly as a brittle shearing along the $\mathrm{E}-\mathrm{W}, \mathrm{NW}-\mathrm{SE}$ and NESW-trending late Archaean zones of weakness (cf. Luukkonen 1985, 1988a,b). Elsewhere all the late Archaean structural patterns are very well preserved, even in the vicinity of the marginal zones of the Saari-Kiekki greenstone belt. The marginal faults of the belt are part of a pattern of late Archaean dextral faults $\left(\mathrm{D}_{4}\right.$ and $\left.\mathrm{D}_{5}\right)$, which were again active during the early Proterozoic Sariolan and Jatulian time.

Fig. 24. Classification of basaltic andesites (filled symbols) and andesites (open symbols) of the Kaita-Kiekki Formation using major-element criteria developed for modern orogenic andesites (Gill 1981).
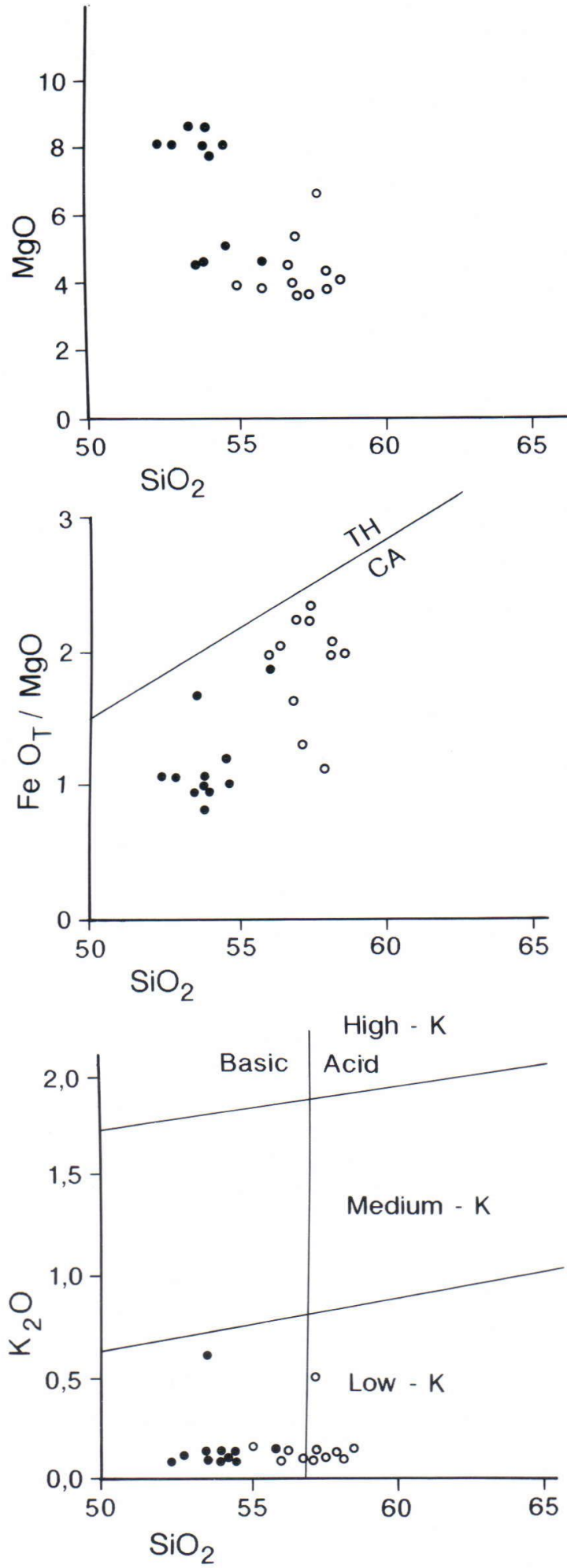

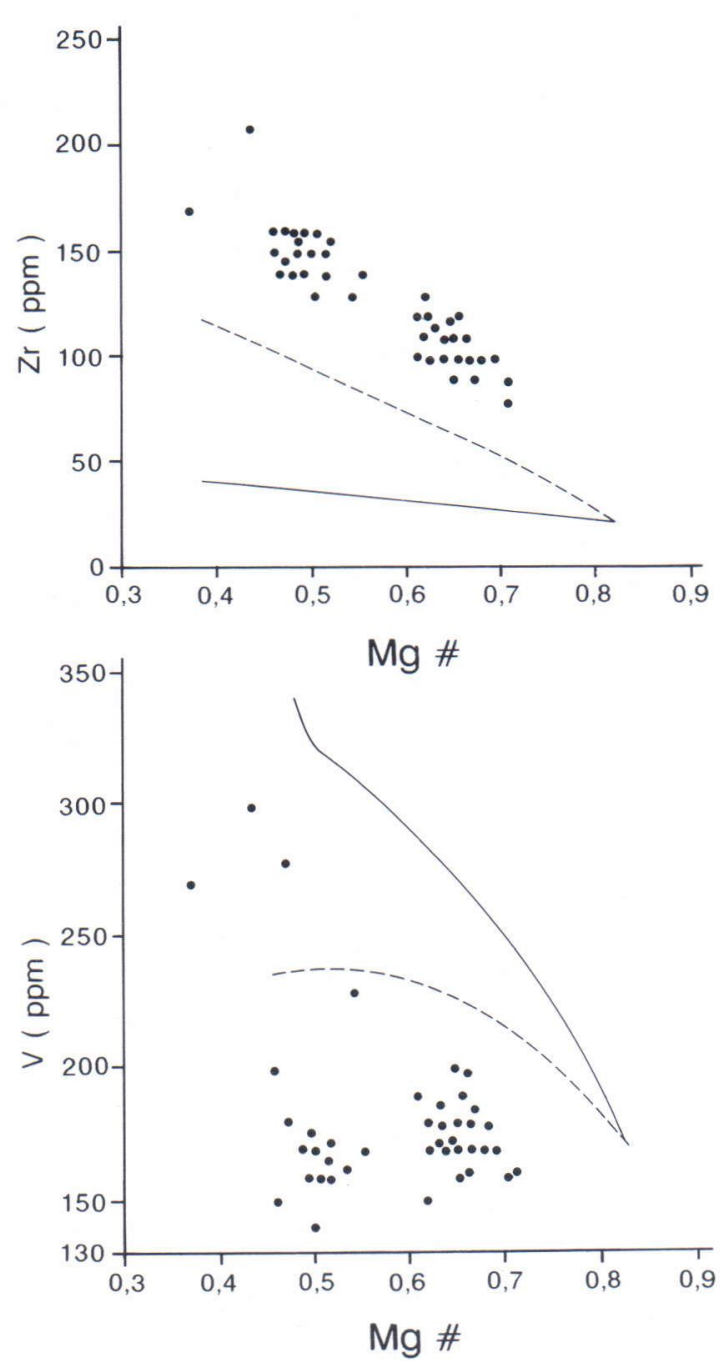

Fig. 25. $\mathrm{Zr}$ and $\mathrm{V}$ against magnesium number $(\mathrm{Mg} \#=$ $\left.\mathrm{Mg} /\left(\mathrm{Fe}_{\text {tot }}+\mathrm{Mg}\right)\right)$ variation diagrams. Solid lines represent fractional crystallization trends from the average komatiitic composition, and dashed lines represent assimilation-fractional crystallization trends calculated using the composition of modern upper crust (Taylor and McLennan 1981), contamination/crystallization ratio of 0.4 was used according to the criteria of Arndt and Jenner 1986.

Within the belt, the cataclastic zones, the narrow volcano-sedimentary layers beneath the lava flows of the Kaita-Kiekki Formation, and the sedimentary rocks of the Latvalampi and Pötsölampi Formations tend to be areas of major movement and thus represent zones of intense and heterogenous strain, resulting from localized discrete structural events during early Proterozoic time.

\section{First deformational phase $\left(D_{\perp}\right)$}

Only in a few outcrops it is possible demonstrate that $S_{1}$ is subparallel to $S_{0}$ (Figs. 5, 9). $S_{1}$ varies in intensity from a relatively weak mineral growth in interiors of the Kaita-Kiekki lava layers to a transposing mylonitic foliation in sedimentary rocks. Folds of the first deformational phase, which are tight to isoclinal with gently to moderately plunging $\mathrm{E}$ - or $\mathrm{W}$-trending fold axes and a moderately dipping axial plane, are well preserved in basic tuffs/tuffites and sublitharenites. Peculiar to and typical of the early stage of intensive $F_{1}$ deformation are »blind» quartz injections a few millimetres thick in the mafic tuffs/tuffites (Fig. 5). The mylonitic features of $S_{1}$ are interpreted as evidence for early gliding in these rock horizons.

\section{Second deformational phase $\left(D_{2}\right)$}

$\mathrm{F}_{2}$ folding comprises open to tight, dextral, overturned folds that deform $\mathrm{S}_{0}$ and $\mathrm{S}_{1} \cdot \mathrm{F}_{2}$ fold axes vary from horizontal to steeply inclined and plunge either $\mathrm{W}-\mathrm{NW}$ or $\mathrm{E}-\mathrm{SE}$. Unlike structures of the earlier deformational phase, the products of the second deformational phase are prominent almost every outcrop; reorientation of earlier structures is frequently seen. Faults with dextral displacement are also common, generally parallel to $\mathrm{F}_{2}$ axial planes, and containing cataclasite and blastomylonite.

Basin-fill thickness is asymmetric with respect to $\mathrm{D}_{2}$ overthrusting, with maximum thickness developed adjacent to the southeastern margins of the major NW-SE faults, and decreasing towards the northwest (cf. Fig. 1, 26). This accounts for the volcanic and sedimentary rocks comprising stacked sequences, lying at a low angle with intraformational unconformities (= »pocket»-like). Similar structural features are found in the Sumi-Sariola Formations of the 


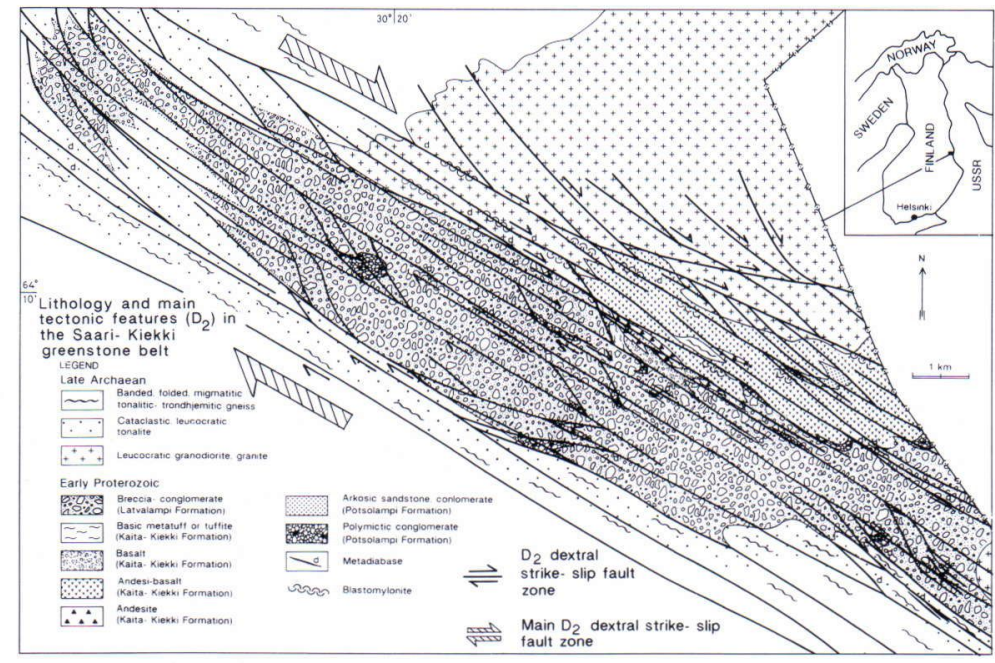

Fig. 26. Main $D_{2}$ dextral strike-slip faults in the study area studied as seen in the field and from topographic maps. Lithologies as in Fig. 1.

Shombozero area in Soviet Karelia (cf. Zhuravlev et al. 1979).

A strong axial planar $\mathrm{S}_{2}$ foliation cuts across $\mathrm{S}_{0}$ and $\mathrm{S}_{1}$. It is developed particularly well in the sedimentary rocks of the Kaita-Kiekki and the Pötsölampi Formations. In many places it is shown by the strong preferred orientation of chlorite, tremolite-actinolite, albite and quartz, which post-dates the $D_{1}$ amphibole, tremolite and oligoclase. In the other rock units $\mathrm{S}_{2}$ is more widely spaced. A strong mineral lineation $\left(\mathrm{L}_{2}\right)$ is expressed by elongate chlorite, younger tremolite and biotite crystal aggregates. The presence of the biotite means that the metamorphism reached the epidote-amphibolite facies PT -conditions during early- $\mathrm{D}_{2}$, and was accompanied by hydration, carbonization, epidotization, albitization and potassium metasomatism in the vicinity of NW-SE-trending fault zones. Increased carbonate and potassium metasomatism resulted in breakdown of Ca-plagioclase and amphibole, and an increasing proportion of chlorite, quartz, albite, calcite and biotite, hence causing incoherent trends in variation diagrams (Figs $21,22,23$ ) and high $\mathrm{Al}_{2} \mathrm{O}_{3}, \mathrm{CaO}$ and $\mathrm{SiO}_{2}$. Metamorphism declined to greenschist facies towards the end of the structural evolution and homogeneous ductile strain was replaced by the late inhomogeneous brittle strain. The $\mathrm{L}_{2}$ lineation is defined by the elongation of amygdules and varioles in lava flows of the Kaita-Kiekki Formation and the elongation of pebbles in the polymictic conglomerates of the Pötsölampi Formation. Other features commonly associated with $\mathrm{D}_{2}$ are blastomylonites, cataclasites and tectonic breccias developed along the $\mathrm{D}_{2}$ dextral fault zones (Fig. 26). These zones may extend from a few centimetres to tens of metres. The most important fault can be traced to the northwest of the studied area as fault zones, zones of weakness or as a lineament for $120 \mathrm{~km}$ or more, and commonly shows late Archaean + early Proterozoic lateral displacement of more than 500 metres in places. The NW-SE-trending diabase dykes show little marginal modification or displacement across the Saari-Kiekki greenstone belt and are interpreted to have been intruded during the later stages of this $\mathrm{D}_{2}$ early Proterozoic deformation.

\section{Third deformational phase $\left(D_{3}\right)$}

Open, commonly symmetrical gently plunging $\mathrm{F}_{3}$ folds have almost vertical $\mathrm{E}-\mathrm{W}$-trending 
axial planes and are only seen to deform earlier structures in outcrops of the mafic tuffs/tuffites. Axial planar fabric is weakly expressed, seen only under the microscope as a parallel orientation of youngest chlorite and sericite.

All three deformational phases noticed in the rocks of the Saari-Kiekki greenstone belt could represent the main stages of dextral, early Proterozoic, NW-SE-trending, parallel strike-slip faults and simple shear along reactivated late $\mathrm{Ar}$ chaean zones of weakness.

\section{Conclusion}

In the Saari-Kiekki area the structures observed in the greenstone belt deform the late Archaean structures, but the greenstone belt itself is cut by the early Proterozoic (c. $2209 \pm 11$ Ma) Jatulian diabase dykes (Fig.1). Furthermore the lithological similarity to the other Sumi-Sariola Formations in Soviet Karelia, and the Sariola in Central Finland invites correlation with the SaariKiekki greenstone belt (cf. Pekkarinen 1979; Marmo 1986; Strand 1988). However, the absence of radiometric age determinations from the volcanic rocks in the area studied makes it difficult to estimate precisely the age of the SaariKiekki greenstone belt. The $2455 \pm 5$ Ma zircon ages for the quartz porphyry dykes of the SumiSariola Formations in Soviet Karelia (Kratz et al. 1976), $2436 \pm 5$ Ma zircon age for the large basic-ultrabasic layered intrusions in Koillismaa (Alapieti 1982) and $2435 \pm 12 \mathrm{Ma}$ zircon age for the granite porphyry dykes in Moisiovaara area (Luukkonen 1988b), are perhaps correlative with the age of the Saari-Kiekki greenstone belt. Its emplacement is an indication of the same phase of continental rifting and coeval strike-slip faulting associated with the break-up of the late Archaean craton (cf. Park et al. 1984).

The immature character of the sediments in the Latvalampi Formation and restricted deposition of breccias and conglomerates, in an elongate, fault-bounded basin indicates increased uplift and rapidly subsiding fault zones, as well as the composition of clasts derived locally from the late Archaean basement rocks, suggests that rapid mechanical erosion surpassed chemical weathering during that time. The presence of arkose layers in the upper part of the Formation gives evidence of a fluvial origin for this unit. The absence of internal sedimentary features in the proximal part of the Formation, probably reflect high topographic relief and fault activity prior to and subsequent to their deposition.

The primary volcanic structures and the composition of the Kaita-Kiekki Formation indicates that they were mainly deposited under subaereal conditions. The composition of the volcanites indicate that they were mantle derived and probably contaminated by crustal material during the underplating before magma ascent if not during their ascent through late Archaean crust. Subsequent autometasomatism during volcanic eruption, and metasomatic processes during $\mathrm{D}_{2}$ early Proterozoic deformational phase have in places extensively altered their composition.

The composition of the Pötsölampi Formation indicates provenance from the late Archaean basement, from the recycled Latvalampi Formation and from the volcanites of the Kaita-Kiekki Formation. Tectonic reactivation resulted in vertical movements during which older and already chemically weathered crust was eroded and redeposited. In places the debris was sorted into mature sands and gravels, perhaps by braided rivers as now recorded by the sublitharenites, arkosic sands-sandstones and polymictic conglomerates. Clast composition and age determinations from the arenites and polymictic conglomerates of the Pötsölampi Formation indicate that late Archaean leucotonalites, granodiorites and tonalites were dominant at the erosion level of the study area during deposition.

Prior to the first deformation in the SaariKiekki area there was a combination of early Proterozoic E-W-trending transcurrence and extension (=transtension) in the dextral strike-slip 
The early Proterozoic Saari-Kiekki greenstone belt: A representative of the Sariola Group at Kuhmo...

a

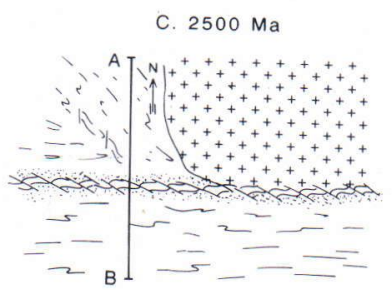

b
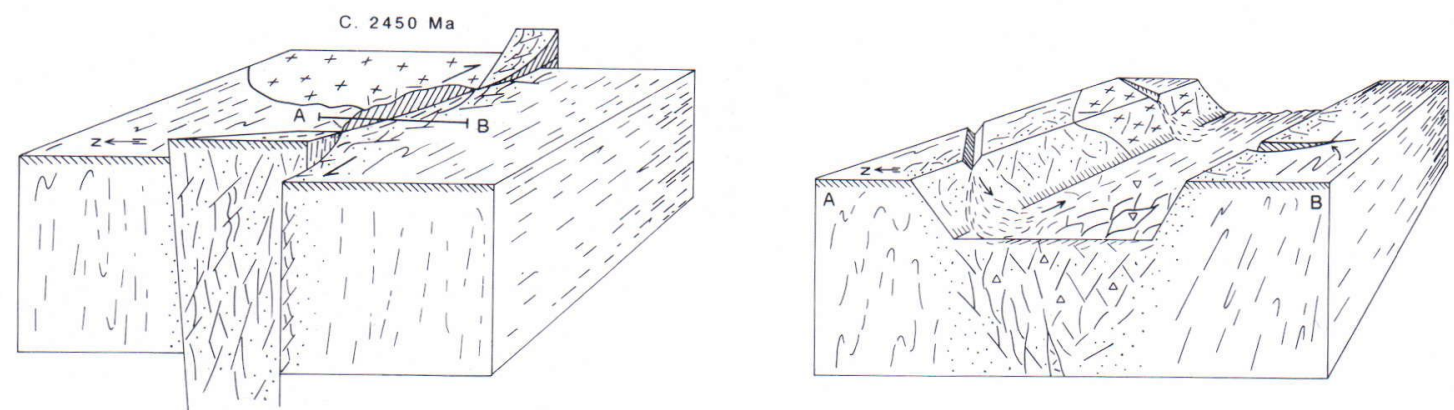

C
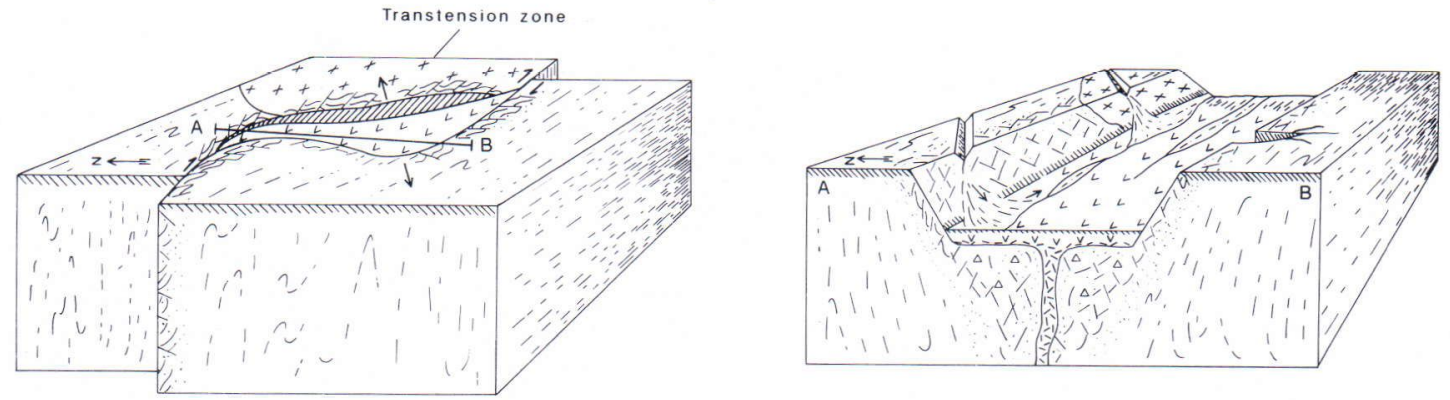

d
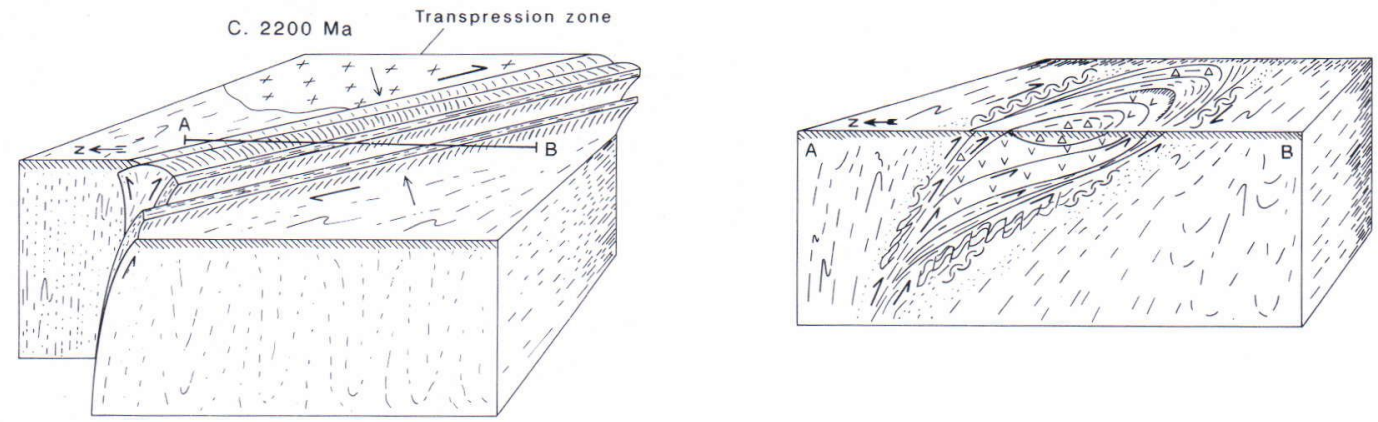

Fig. 27. Schematic models for the four main stages of deformation and deposition during Sariola time in the Saari-Kiekki area. a) Earliest Proterozoic reactivation c. 2500-2450 Ma following late Archaean polyphase deformation; divergent and convergent fault patterns; incipient strike-slip zone. Compare with map in Fig.1. b) Stage of transtension; deposition of the Latvalampi Formation, and initial ascent mafic magma through the crust. c) Continuing extension; deposition of the Kaita-Kiekki and the Pötsölampi Formations. d) Stage of transpression; overthrusting and evolution of the flower structure c. $2200 \mathrm{Ma}$. 
fault zone. When the dextral, E-W-trending strike-slip movement contains the same sense of shear as that of the main fault, it leads to extension of the sector, stratal thinning and the development of normal fault systems obliquely inclined ( $=\mathrm{NW}-\mathrm{SE}$ trend) to the strike of the main fault. This reactivated both the $\mathrm{E}-\mathrm{W}$ and NW-SE-trending late Archaean $\left(\mathrm{D}_{5}\right.$ and $\left.\mathrm{D}_{4}\right)$ zone of weakness (Fig. 27a), which together give alternate zones of divergence and convergence and are formed within continental crust. At first the extension was limited, causing »small sag ponds» along the strike-slip fault. The deposition of breccias and conglomerates of the Latvalampi Formation at the basin margins represents talus detritus or alluvial fans (Fig. 27b). As extension proceeded, crustal thinning allowed magma to rise and basalts, basaltic andesites and andesites of the Kaita-Kiekki Formation extruded. The latter part of the evolution of the SaariKiekki greenstone belt is typified by various mass gravity transport processes. Redeposition of the earlier material commenced, with the stratified sediments and the conglomerates of the Pötsölampi Formation and breccias continued to form at the faulted margins (Fig. 27c).

The first and second deformational phases in the structural history are marked by transpressive regimes: strike-slip faulting of $\mathrm{E}-\mathrm{W}$ and NW-SE trend, overthrusting, folding and uplift. In the NW-SE-trending strike-slip fault (= in the reactivated late Archaean $\mathrm{D}_{4}$ zone of weakness), the strong transpression lead to the tectonic extrusion of the Saari-Kiekki greenstone belt, resulting in a series of convex upward reversed, or thrust faults, forming a structure better known as a flower - or palm tree-structure
(Fig. 27d; cf. Harding 1985, Ramsay and Huber 1987, Sylvester 1988). The present Saari-Kiekki greenstone belt is interpreted as an eroded, early Proterozoic positive flower structure. The later stage of $\mathrm{D}_{2}$ leads in places to the intrusion of NW-SE-trending Jatulian $(2209 \pm 11 \mathrm{Ma})$ diabase dykes and the $\mathrm{D}_{3}$ in the structural history possibly represents the latest stage of this transpression.

The late Archaean reactivated zones of weakness in the Saari-Kiekki area have changed from a transtensile regime in the Sariolan time to a transpressive one in the Jatulian time and caused »stratal shingling» which is younging towards the depocenter. This type of the change from one regime to another is also typical for younger strikeslip fault systems (Nardin \& Henyey 1978; Carter \& Norris 1976; Norris et al.,1978; Reading 1980; Hempton et al. 1983), and seen as well in the much more extensive Sumi-Sariola Formations of Soviet Karelia (cf. Zhuralev et al. 1979).

As a whole the reactivated late Archaean zone of weakness has been both the depocenter for Sariolan sediments and volcanites, and later on, where the volcano-sedimentary succession was preserved from subsequent erosion (= »pocket»like formations in the reactivated late Archaean fault zone).

Acknowledgement. This work was supported by the Geological Survey of Finland. The author wishes to express his gratitude to Dr. O. Kouvo and his co-workers for arranging the radiometric age determinations, to Prof. $\mathrm{H}$. Papunen and colleages in the Survey for many fruitful discussions and advice. Mrs Anni Vuori drew the map and the diagrams, and Dr. Peter Ward corrected the English in the manuscript. I am deeply grateful to both of them. 
Table 1. Chemical analyses of volcanic and sedimentary rocks from the Kaita-Kiekki and Pötsölampi Formations: $1-40$ Kaita-Kiekki Formation, 1-4. Mafic tuff/tuffite, 5-16. Komatiitic-high magnesium basalt, 17-28. Basaltic andesite and 29-40. Andesite; 41-43. Jatulian diabase dyke; 44-46 Pötsölampi formation, 44. Sublitharenite, 45. Arkosoc sandstone and 46. Arkosic sandstone - conglomerate.

\begin{tabular}{|c|c|c|c|c|c|c|c|c|c|c|c|c|c|}
\hline & 1 & 2 & 3 & 4 & 5 & 6 & 7 & 8 & 9 & 10 & 11 & 12 & 13 \\
\hline $\mathrm{SiO}_{2}$ & 55.10 & 49.70 & 46.90 & 48.00 & 51.20 & 48.10 & 51.90 & 49.00 & 44.90 & 52.90 & 54.50 & 57.70 & 53.90 \\
\hline $\mathrm{TiO}_{2}$ & 0.44 & 0.47 & 0.60 & 0.50 & 0.48 & 0.48 & 0.50 & 0.58 & 0.47 & 0.44 & 0.51 & 0.49 & 0.46 \\
\hline $\mathrm{Al}_{2} \mathrm{O}_{3}$ & 10.40 & 14.30 & 14.40 & 14.60 & 12.40 & 10.30 & 13.50 & 18.70 & 12.00 & 16.70 & 12.90 & 15.00 & 12.30 \\
\hline $\mathrm{Fe}_{2} \mathrm{O}_{3}$ tot & 9.47 & 10.07 & 11.02 & 10.92 & 9.71 & 12.80 & 9.99 & 9.81 & 12.98 & 7.87 & 9.08 & 7.20 & 9.66 \\
\hline $\mathrm{MnO}$ & 0.22 & 0.16 & 0.17 & 0.25 & 0.18 & 0.23 & 0.19 & 0.13 & 0.27 & 0.16 & 0.16 & 0.12 & 0.17 \\
\hline $\mathrm{MgO}$ & 10.30 & 8.74 & 9.48 & 8.67 & 9.95 & 11.00 & 8.25 & 2.56 & 10.80 & 5.67 & 7.55 & 5.27 & 8.30 \\
\hline $\mathrm{CaO}$ & 8.10 & 10.30 & 10.70 & 10.10 & 7.51 & 9.74 & 8.46 & 11.40 & 10.70 & 11.60 & 11.20 & 10.90 & 10.20 \\
\hline $\mathrm{Na}_{2} \mathrm{O}$ & 0.41 & 0.95 & 1.03 & 1.48 & 2.72 & 1.96 & 3.56 & 3.50 & 1.06 & 1.00 & 0.47 & 0.63 & 0.63 \\
\hline $\mathrm{K}_{2} \mathrm{O}$ & 0.09 & 0.62 & 0.69 & 0.16 & 1.29 & 0.14 & 0.08 & 0.17 & 0.43 & 0.23 & 0.14 & 0.13 & 0.20 \\
\hline $\mathrm{P}_{2} \mathrm{O}_{5}$ & 0.07 & 0.13 & 0.09 & 0.10 & 0.10 & 0.09 & 0.10 & 0.14 & 0.06 & 0.19 & 0.09 & 0.12 & 0.09 \\
\hline L.O.I. & 0.14 & 1.07 & 0.74 & 0.87 & 0.68 & 0.38 & 0.25 & 0.84 & 1.10 & 0.64 & 0.62 & 0.43 & 0.69 \\
\hline Total & 94.90 & 95.70 & 95.30 & 95.00 & 95.70 & 95.00 & 96.80 & 96.10 & 93.80 & 96.90 & 96.80 & 97.90 & 96.10 \\
\hline $\mathrm{V}(\mathrm{ppm})$ & 160 & 180 & 200 & 200 & 170 & 180 & 190 & 270 & 200 & 150 & 170 & 170 & 170 \\
\hline $\mathrm{Cr}$ & 1140 & 640 & 680 & 610 & 800 & 630 & 620 & 20 & 540 & 500 & 540 & 570 & 550 \\
\hline $\mathrm{Cu}$ & 90 & 10 & 10 & 10 & 40 & 200 & 40 & 130 & 10 & 150 & 90 & 230 & 10 \\
\hline $\mathrm{Zn}$ & 100 & 70 & 80 & 310 & 60 & 130 & 100 & 120 & 120 & 70 & 110 & 80 & 110 \\
\hline $\mathrm{Ni}$ & 240 & 180 & 200 & 180 & 230 & 210 & 180 & 50 & 210 & 110 & 170 & 130 & 160 \\
\hline S & 210 & 230 & 150 & 280 & 200 & 150 & 370 & 530 & 210 & 510 & 430 & 1600 & 180 \\
\hline $\mathrm{Ba}$ & 40 & 270 & 290 & 30 & 290 & 30 & 20 & 70 & 190 & 70 & 20 & 20 & 40 \\
\hline $\mathrm{Sr}$ & 170 & 290 & 250 & 270 & 150 & 60 & 100 & 460 & 60 & 280 & 300 & 380 & 210 \\
\hline $\mathrm{Zr}$ & 90 & 120 & 120 & 110 & 100 & 90 & 100 & 170 & 80 & 110 & 110 & 120 & 100 \\
\hline
\end{tabular}

$1=86-\mathrm{B}-78,2=336-\mathrm{A}-81,3=336-\mathrm{B}-81,4=353-\mathrm{A}-87,5=272-\mathrm{C}-80,6=87-\mathrm{B}-78,7=269-\mathrm{A}-80,8=358-\mathrm{B}-81$, $9=356-\mathrm{A}-87,10=356-\mathrm{B}-87,11=356-\mathrm{C}-87,12=356-\mathrm{D}-87,13=356-\mathrm{E}-87$

\begin{tabular}{|c|c|c|c|c|c|c|c|c|c|c|c|c|c|}
\hline & 14 & 15 & 16 & 17 & 18 & 19 & 20 & 21 & 22 & 23 & 24 & 25 & 26 \\
\hline $\mathrm{SiO}_{2}$ & 50.90 & 51.90 & 51.20 & 53.80 & 52.30 & 54.60 & 54.60 & 52.90 & 54.10 & 54.00 & 54.00 & 55.90 & 53.60 \\
\hline $\mathrm{TiO}_{2}$ & 0.51 & 0.47 & 1.37 & 0.41 & 0.50 & 0.51 & 0.42 & 0.47 & 0.50 & 0.47 & 0.62 & 0.64 & 0.66 \\
\hline $\mathrm{Al}_{2} \mathrm{O}_{3}$ & 12.80 & 13.90 & 15.10 & 10.30 & 13.40 & 12.00 & 17.20 & 13.30 & 13.40 & 11.40 & 15.50 & 14.40 & 16.00 \\
\hline $\mathrm{Fe}_{2} \mathrm{O}_{3}$ tot & 10.73 & 10.44 & 13.73 & 9.96 & 9.61 & 9.10 & 6.91 & 9.61 & 8.45 & 9.66 & 12.16 & 9.80 & 8.57 \\
\hline $\mathrm{MnO}$ & 0.20 & 0.20 & 0.23 & 0.23 & 0.19 & 0.12 & 0.13 & 0.18 & 0.16 & 0.21 & 0.21 & 0.15 & 0.18 \\
\hline $\mathrm{MgO}$ & 9.42 & 7.91 & 2.54 & 10.70 & 8.08 & 8.01 & 5.08 & 8.09 & 7.83 & 8.56 & 4.60 & 4.58 & 4.56 \\
\hline $\mathrm{CaO}$ & 7.60 & 7.33 & 8.37 & 8.85 & 7.73 & 9.08 & 12.20 & 7.53 & 8.20 & 10.00 & 4.91 & 6.49 & 7.88 \\
\hline $\mathrm{Na}_{2} \mathrm{O}$ & 1.67 & 3.91 & 2.82 & 0.54 & 3.81 & 3.02 & 0.85 & 3.92 & 4.05 & 1.62 & 5.07 & 5.21 & 4.34 \\
\hline $\mathrm{K}_{2} \mathrm{O}$ & 1.98 & 0.09 & 0.97 & 0.11 & 0.09 & 0.09 & 0.12 & 0.11 & 0.07 & 0.13 & 0.09 & 0.11 & 0.13 \\
\hline $\mathrm{P}_{2} \mathrm{O}_{5}$ & 0.09 & 0.09 & 0.21 & 0.06 & 0.10 & 0.10 & 0.12 & 0.09 & 0.10 & 0.08 & 0.13 & 0.13 & 0.19 \\
\hline L.O.I. & 0.70 & 0.47 & 0.27 & 1.17 & 0.30 & 0.18 & 0.38 & 0.34 & 0.20 & 0.31 & 0.20 & 0.19 & 0.20 \\
\hline Total & 96.30 & 96.60 & 96.70 & 95.30 & 96.00 & 96.90 & 98.10 & 96.40 & 97.10 & 96.40 & 97.50 & 97.50 & 96.40 \\
\hline $\mathrm{V}(\mathrm{ppm})$ & 190 & 170 & 270 & 160 & 180 & 180 & 180 & 170 & 170 & 160 & 200 & 160 & 230 \\
\hline $\mathrm{Cr}$ & 610 & 580 & 30 & 1040 & 590 & 580 & 940 & 540 & 620 & 530 & 30 & 30 & 730 \\
\hline $\mathrm{Cu}$ & 20 & 340 & 90 & 10 & 30 & 20 & 1150 & 40 & 10 & 30 & 20 & 20 & 20 \\
\hline $\mathrm{Zn}$ & 80 & 80 & 150 & 90 & 70 & 70 & 80 & 100 & 90 & 170 & 280 & 180 & 100 \\
\hline $\mathrm{Ni}$ & 190 & 180 & 50 & 230 & 170 & 160 & 110 & 160 & 180 & 170 & 100 & 90 & 170 \\
\hline $\mathrm{S}$ & 460 & 780 & 1320 & 110 & 180 & 100 & 1510 & 170 & 120 & 200 & 70 & 210 & 250 \\
\hline $\mathrm{Ba}$ & 1210 & 70 & 330 & 60 & 50 & 40 & 30 & 40 & 20 & 30 & 30 & 10 & 50 \\
\hline $\mathrm{Sr}$ & 240 & 150 & 170 & 170 & 140 & 130 & 600 & 110 & 140 & 180 & 130 & 140 & 170 \\
\hline $\mathrm{Zr}$ & 110 & 100 & 260 & 80 & 100 & 100 & 130 & 90 & 100 & 100 & 150 & 150 & 130 \\
\hline
\end{tabular}

$14=196-\mathrm{B}-86,15=196-\mathrm{D}-86,16=274-\mathrm{B}-80,17=357-87,18=272-\mathrm{A}-80,19=272-\mathrm{B}-80,20=86-\mathrm{A}-78,21=87-\mathrm{A}-78$, $22=87-\mathrm{C}-78,23=87-\mathrm{D}-78,24=357-\mathrm{C}-81,25=358-\mathrm{A}-81,26=199-\mathrm{A}-85$ 
Table 1. Continued.

\begin{tabular}{|c|c|c|c|c|c|c|c|c|c|c|c|c|c|}
\hline & 27 & 28 & 29 & 30 & 31 & 32 & 33 & 34 & 35 & 36 & 37 & 38 & 39 \\
\hline $\mathrm{SiO}_{2}$ & 53.60 & 53.90 & 56.00 & 58.60 & 56.40 & 58.20 & 55.10 & 57.50 & 58.20 & 57.00 & 57.30 & 56.90 & 57.90 \\
\hline $\mathrm{TiO}_{2}$ & 0.47 & 0.50 & 0.59 & 0.65 & 0.62 & 0.62 & 0.64 & 0.66 & 0.64 & 0.62 & 0.62 & 0.58 & 0.47 \\
\hline $\mathrm{Al}_{2} \mathrm{O}_{3}$ & 12.90 & 13.20 & 15.80 & 13.80 & 14.50 & 15.00 & 17.00 & 15.60 & 15.00 & 15.00 & 14.90 & 15.10 & 13.40 \\
\hline $\mathrm{Fe}_{2} \mathrm{O}_{3 \text { tot }}$ & 9.21 & 9.26 & 8.83 & 9.36 & 10.70 & 10.00 & 10.00 & 9.70 & 9.03 & 10.19 & 9.37 & 8.37 & 8.34 \\
\hline $\mathrm{MnO}$ & 0.16 & 0.24 & 0.21 & 0.18 & 0.21 & 0.19 & 0.16 & 0.21 & 0.18 & 0.19 & 0.18 & 0.16 & 0.13 \\
\hline $\mathrm{MgO}$ & 8.57 & 7.96 & 4.02 & 4.23 & 4.73 & 4.47 & 3.98 & 3.74 & 3.94 & 4.11 & 3.76 & 4.67 & 6.77 \\
\hline $\mathrm{CaO}$ & 8.76 & 7.53 & 6.26 & 7.11 & 6.15 & 5.06 & 5.90 & 5.12 & 5.45 & 5.23 & 6.03 & 6.41 & 4.58 \\
\hline $\mathrm{Na}_{2} \mathrm{O}$ & 2.24 & 3.66 & 5.50 & 3.46 & 4.11 & 4.43 & 4.79 & 5.38 & 5.12 & 5.32 & 5.08 & 4.63 & 2.11 \\
\hline $\mathrm{K}_{2} \mathrm{O}$ & 0.62 & 0.09 & 0.11 & 0.15 & 0.13 & 0.11 & 0.15 & 0.11 & 0.10 & 0.10 & 0.13 & 0.10 & 3.33 \\
\hline $\mathrm{P}_{2} \mathrm{O}_{5}$ & 0.10 & 0.12 & 0.14 & 0.15 & 0.14 & 0.12 & 0.16 & 0.10 & 0.15 & 0.13 & 0.14 & 0.12 & 0.08 \\
\hline L.O.I. & 0.54 & 0.39 & 0.18 & 0.19 & 0.01 & 0.08 & 0.01 & 0.01 & 0.01 & 0.01 & 0.01 & 0.29 & 1.00 \\
\hline Total & 96.90 & 96.70 & 97.50 & 97.90 & 97.90 & 98.30 & 98.10 & 98.30 & 97.90 & 98.00 & 97.70 & 97.20 & 97.40 \\
\hline $\mathrm{V}(\mathrm{ppm})$ & 170 & 160 & 160 & 140 & 160 & 170 & 280 & 150 & 170 & 180 & 180 & 170 & 170 \\
\hline $\mathrm{Cr}$ & 680 & 600 & 50 & 30 & 30 & 30 & 40 & 30 & 30 & 40 & 30 & 80 & 580 \\
\hline $\mathrm{Cu}$ & 140 & 10 & 50 & 20 & 40 & 10 & 530 & 60 & 30 & 10 & 90 & 70 & 10 \\
\hline $\mathrm{Zn}$ & 60 & 240 & 110 & 120 & 140 & 140 & 130 & 140 & 130 & 150 & 150 & 150 & 120 \\
\hline $\mathrm{Ni}$ & 210 & 200 & 80 & 90 & 90 & 80 & 70 & 90 & 80 & 80 & 80 & 90 & 170 \\
\hline $\mathrm{S}$ & 500 & 330 & 200 & 80 & 90 & 70 & 920 & 250 & 170 & 120 & 130 & 320 & 410 \\
\hline $\mathrm{Ba}$ & 220 & 50 & 30 & 20 & 40 & 30 & 40 & 0 & 40 & 50 & 40 & 40 & 260 \\
\hline $\mathrm{Sr}$ & 180 & 110 & 120 & 160 & 140 & 120 & 140 & 180 & 160 & 140 & 150 & 160 & 250 \\
\hline $\mathrm{Zr}$ & 100 & 100 & 130 & 160 & 150 & 140 & 160 & 160 & 160 & 140 & 150 & 140 & 110 \\
\hline
\end{tabular}

$27=271-\mathrm{A}-80,28=197-\mathrm{A}-86,29=360-\mathrm{A}-81,30=82-\mathrm{A}-78,31=82-\mathrm{B}-78,32=82-\mathrm{C}-78,33=82-\mathrm{D}-78,34=82-\mathrm{E}-78$, $35=82-\mathrm{F}-78,36=82-\mathrm{G}-78,37=82-\mathrm{H}-78,38=85-\mathrm{A}-78,39=198-86$

\begin{tabular}{lrrrrrrr}
\hline & 40 & 41 & 42 & 43 & 44 & 45 & 46 \\
\hline $\mathrm{SiO}_{2}$ & 57.10 & 47.80 & 51.90 & 51.50 & 72.00 & 78.40 & 70.80 \\
$\mathrm{TiO}_{2}$ & 0.46 & 0.47 & 1.70 & 0.50 & 0.31 & 0.20 & 0.34 \\
$\mathrm{Al}_{2} \mathrm{O}_{3}$ & 14.30 & 14.50 & 13.70 & 13.30 & 14.90 & 12.70 & 14.70 \\
$\mathrm{Fe}_{2} \mathrm{O}_{3}$ tot & 7.95 & 8.63 & 12.13 & 10.03 & 2.46 & 0.73 & 3.81 \\
$\mathrm{MnO}$ & 0.16 & 0.21 & 0.15 & 0.18 & 0.02 & 0.01 & 0.03 \\
$\mathrm{MgO}$ & 5.54 & 6.19 & 4.14 & 8.49 & 1.38 & 0.32 & 1.66 \\
$\mathrm{CaO}$ & 8.26 & 16.20 & 8.62 & 7.59 & 1.33 & 0.44 & 1.11 \\
$\mathrm{Na}$ & 2.46 & 0.21 & 4.26 & 3.25 & 3.47 & 4.48 & 5.14 \\
$\mathrm{~K}_{2} \mathrm{O}$ & 0.51 & 0.02 & 0.44 & 0.58 & 2.57 & 1.58 & 0.48 \\
$\mathrm{P} \mathrm{O}_{5}$ & 0.10 & 0.09 & 0.18 & 0.09 & 0.02 & 0.01 & 0.10 \\
$\mathrm{L.O} . \mathrm{I}$. & 0.37 & 1.55 & 0.48 & 0.91 & 1.11 & 0.59 & 1.20 \\
$\mathrm{Total}$ & 97.20 & 94.50 & 97.60 & 95.80 & 98.50 & 99.00 & 98.40 \\
$\mathrm{~V}$ (ppm) & 190 & 190 & 300 & 180 & 90 & 40 & 90 \\
$\mathrm{Cr}$ & 540 & 600 & 20 & 610 & 100 & 40 & 130 \\
$\mathrm{Cu}$ & 20 & 310 & 200 & 10 & 30 & 10 & 350 \\
$\mathrm{Zn}$ & 50 & 100 & 40 & 80 & 40 & 10 & 60 \\
$\mathrm{Ni}$ & 120 & 130 & 70 & 180 & 50 & 30 & 60 \\
$\mathrm{~S}$ & 440 & 550 & 4110 & 350 & 280 & 100 & 1550 \\
$\mathrm{Ba}$ & 370 & 30 & 60 & 260 & 470 & 170 & 90 \\
$\mathrm{Sr}$ & 430 & 110 & 420 & 130 & 100 & 40 & 70 \\
$\mathrm{Zr}$ & 120 & 100 & 210 & 100 & 100 & 120 & 150 \\
\hline
\end{tabular}

$40=196-\mathrm{A}-86,41=202-\mathrm{A}-86,42=363-\mathrm{A}-81,43=274-\mathrm{A}-80,44=83-\mathrm{A}-78,45=83-\mathrm{B}-78,46=84-\mathrm{A}-78$ 
Table 2. U-Pb isotopic data. Location of samples are in text and in Figure 1. Hand-picked zircons were analysed in the laboratories of the Geological Survey of Finland. All ages are calculated or recalculated with the decay constants as recommended by Jaffey et al. (1971).

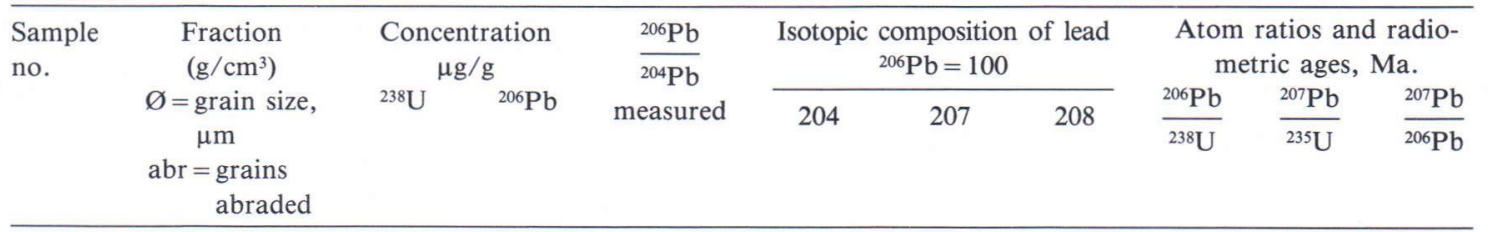

A185-Kivi-Kiekki, Kuhmo; leucocratic tonalite

\begin{tabular}{|c|c|c|c|c|c|c|c|c|c|c|}
\hline A185A & $\begin{array}{l}d>4.6 \\
70<\varnothing<160\end{array}$ & 225.6 & 89.28 & 2077 & .04678 & 19.133 & 42.066 & $\begin{array}{l}.4574 \\
\pm 24 \\
2428\end{array}$ & $\begin{array}{c}11.708 \\
\pm 63 \\
2581\end{array}$ & $\begin{array}{l}.18566 \\
\pm \quad 12 \\
2704\end{array}$ \\
\hline B & $\begin{array}{l}4.2<d<4.6 \\
70<\varnothing<160\end{array}$ & 481.7 & 162.93 & 1260 & .07883 & 18.480 & 7.026 & $\begin{array}{l}.3910 \\
\pm 21 \\
2127\end{array}$ & $\begin{array}{c}9.440 \\
\pm 52 \\
2381\end{array}$ & $\begin{array}{l}.17512 \\
\pm \quad 9 \\
2607\end{array}$ \\
\hline C & $\begin{array}{c}\mathrm{d}>4.5 ; \varnothing<70 \\
\mathrm{abr}\end{array}$ & 304.4 & 127.45 & 2646 & .03424 & 19.277 & 9.865 & $\begin{array}{c}.4839 \\
\pm 32 \\
2544\end{array}$ & $\begin{array}{c}12.585 \\
\pm 86 \\
2649\end{array}$ & $\begin{array}{l}.18863 \\
\pm \quad 22 \\
2730\end{array}$ \\
\hline D & $\begin{array}{c}4.0<\mathrm{d}<4.2 \\
\text { abr }\end{array}$ & 1039 & 304.27 & 1435 & .06662 & 17.207 & 4.990 & $\begin{array}{l}.3385 \\
\pm 25 \\
1879\end{array}$ & $\begin{array}{c}7.642 \\
\pm 59 \\
2189\end{array}$ & $\begin{array}{l}.1637 \\
\pm \quad 2 \\
2494\end{array}$ \\
\hline
\end{tabular}

A911-Latvalampi, Kaita-Kiekki, Kuhmo; a granitoid boulder in conglomerate

\begin{tabular}{|c|c|c|c|c|c|c|c|c|c|c|}
\hline \multirow[b]{2}{*}{ A911A } & \multirow[b]{2}{*}{$d>4.6$} & \multirow[b]{2}{*}{330.5} & \multirow[b]{2}{*}{124.00} & \multirow[b]{2}{*}{2629} & \multirow[b]{2}{*}{.02910} & \multirow[b]{2}{*}{18.130} & \multirow[b]{2}{*}{12.779} & \multirow[b]{2}{*}{$\begin{array}{l}.4336 \\
\pm 23 \\
2322\end{array}$} & \multirow[b]{2}{*}{$\begin{array}{r}10.625 \\
\pm 66 \\
2490\end{array}$} & \multirow[b]{2}{*}{$\begin{array}{l}.17772 \\
\pm \quad 44 \\
2631\end{array}$} \\
\hline & & & & & & & & & & \\
\hline B & $4.2<d<4.6$ & 443.6 & 149.04 & 823.8 & .11143 & 18.587 & 18.474 & $\begin{array}{l}.2883 \\
\pm 26 \\
2115\end{array}$ & $\begin{array}{c}9.212 \\
\pm 66 \\
2359\end{array}$ & $\begin{array}{l}.17207 \\
\pm \quad 28 \\
2578\end{array}$ \\
\hline $\mathrm{C}$ & $4.0<\mathrm{d}<4.2$ & 680.7 & 207.70 & 1003 & .09845 & 17.646 & 17.843 & $\begin{array}{l}.3527 \\
\pm 21 \\
1947\end{array}$ & $\begin{array}{l}7.982 \\
\pm 49 \\
2228\end{array}$ & $\begin{array}{l}.16416 \\
\pm \quad 12 \\
2499\end{array}$ \\
\hline $\mathrm{D}$ & $3.8<\mathrm{d}<4.0$ & 992.6 & 235.94 & 583.3 & .16935 & 17.057 & 22.998 & $\begin{array}{l}.2747 \\
\pm 15 \\
1564\end{array}$ & $\begin{array}{l}5.646 \\
\pm 34 \\
1923\end{array}$ & $\begin{array}{l}.14906 \\
\pm \quad 32 \\
2335\end{array}$ \\
\hline \multicolumn{11}{|c|}{ A913-Pötsölampi, Kuhmo; arkosite (coarse-grained) } \\
\hline A913A & $\mathrm{d}>4.2$ & 484.9 & 114.64 & 5344 & .01346 & 18.165 & 14.693 & $\begin{array}{l}.2733 \\
\pm 14 \\
1557\end{array}$ & $\begin{array}{l}6.782 \\
\pm 37 \\
2083\end{array}$ & $\begin{array}{l}.18001 \\
\pm \quad 14 \\
2653\end{array}$ \\
\hline B & $\begin{array}{l}4.0<\mathrm{d}<4.2 \\
\varnothing>70\end{array}$ & 808.9 & 180.72 & 4805 & .01897 & 17.539 & 14.423 & $\begin{array}{l}.2582 \\
\pm 13 \\
1480\end{array}$ & $\begin{array}{l}6.161 \\
\pm 33 \\
1998\end{array}$ & $\begin{array}{l}.17305 \\
\pm \quad 18 \\
2587\end{array}$ \\
\hline $\mathrm{C}$ & $3.8<\mathrm{d}<4.0$ & 1155 & 206.79 & 1551 & .06061 & 17.028 & 16.089 & $\begin{array}{l}.2070 \\
\pm 11 \\
1212\end{array}$ & $\begin{array}{l}4.644 \\
\pm 25 \\
1757\end{array}$ & $\begin{array}{l}.16274 \\
\pm \quad 12 \\
2484\end{array}$ \\
\hline $\mathrm{D}$ & $\begin{array}{l}4.0<\mathrm{d}<4.2 \\
\text { violet; } \mathrm{abr}\end{array}$ & 653.7 & 212.24 & 4177 & .02262 & 17.825 & 14.864 & $\begin{array}{l}.3753 \\
\pm 19 \\
2054\end{array}$ & $\begin{array}{l}9.079 \\
\pm 48 \\
2346\end{array}$ & $\begin{array}{l}.17549 \\
\pm \quad 10 \\
2610\end{array}$ \\
\hline $\mathrm{E}$ & $\begin{array}{l}4.0<\mathrm{d}<4.2 \\
\text { yellowish } \\
\varnothing>130 ; \text { abr }\end{array}$ & 547.1 & 170.10 & 3108 & .03024 & 18.383 & 16.972 & $\begin{array}{l}.3593 \\
\pm 23 \\
1979\end{array}$ & $\begin{array}{l}8.925 \\
\pm 59 \\
2330\end{array}$ & $\begin{array}{l}.18016 \\
\pm \quad 15 \\
2654\end{array}$ \\
\hline $\mathrm{F}$ & $\begin{array}{l}4.0<\mathrm{d}<4.2 \\
\text { euhedral; dark } \\
\varnothing>130 ; \text { abr }\end{array}$ & 725.2 & 236.40 & 3843 & .02374 & 17.743 & 13.901 & $\begin{array}{l}.3767 \\
\pm 22 \\
2060\end{array}$ & $\begin{array}{r}9.065 \\
\pm 54 \\
2344\end{array}$ & $\begin{array}{l}.17453 \\
\pm \quad 23 \\
2601\end{array}$ \\
\hline
\end{tabular}


Table 2. Continued.

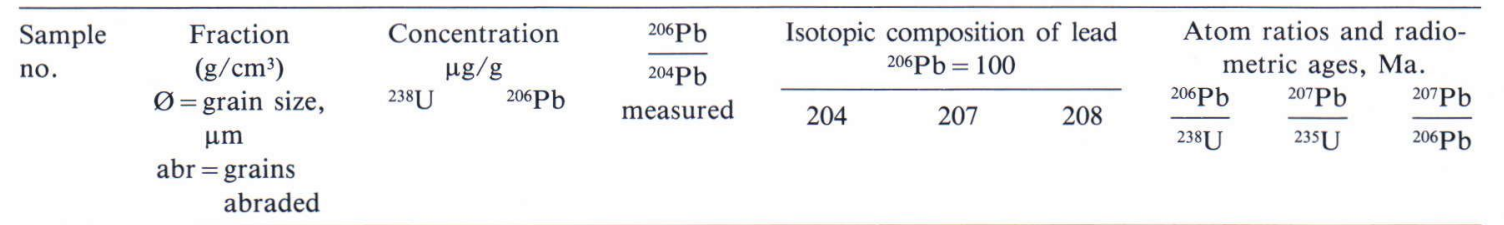

A912-Pötsölampi, Kuhmo; arkosite (fine-grained)

912A $\quad 4.0<d<4.2 \quad 878.1 \quad 177.25 \quad 2145$

\begin{tabular}{|c|c|c|c|c|c|c|c|c|c|c|}
\hline & $4.0<\mathrm{d}<4.2$ & 878.1 & 177.25 & 2145 & .04380 & 17.838 & 18.304 & $\begin{array}{r}.2333 \\
\pm 12\end{array}$ & $\begin{array}{r}5.564 \\
\pm \quad 30 \\
\end{array}$ & $\begin{array}{r}.17296 \\
\pm \quad 12\end{array}$ \\
\hline B & $\begin{array}{c}3.8<\mathrm{d}<4.0 \\
\varnothing>70\end{array}$ & 1268 & 198.35 & 1842 & .05162 & 16.973 & 18.142 & $\begin{array}{l}1351 \\
.18082 \\
\pm 94 \\
1071\end{array}$ & $\begin{array}{c}1910 \\
4.071 \\
\pm 22 \\
1648\end{array}$ & $\begin{array}{l}2586 \\
.16328 \\
\pm \quad 10 \\
2490\end{array}$ \\
\hline $\mathrm{C}$ & $\mathrm{d}>4.2$ & 502.2 & 115.60 & 2119 & .03983 & 18.621 & 18.563 & $\begin{array}{c}.2660 \\
\pm 14 \\
1520\end{array}$ & $\begin{array}{r}6.651 \\
\pm \quad 37 \\
2066\end{array}$ & $\begin{array}{l}.18133 \\
\pm \quad 22 \\
2665\end{array}$ \\
\hline $\mathrm{D}$ & $\begin{array}{c}4.0<\mathrm{d}<4.2 \\
\text { abr }\end{array}$ & 559.4 & 190.63 & 7524 & .01131 & 17.913 & 15.309 & $\begin{array}{c}.3939 \\
\pm 64 \\
2140\end{array}$ & $\begin{array}{l}9.65 \\
\pm 16 \\
2402\end{array}$ & $\begin{array}{l}.17774 \\
\pm \quad 30 \\
2632\end{array}$ \\
\hline
\end{tabular}

A186-Saari-Kiekki, Kuhmo; granitoid boulder in the volcanic conglomerate

\begin{tabular}{|c|c|c|c|c|c|c|c|c|c|c|}
\hline & & & & & & & & & & \\
\hline A186A & $\begin{array}{c}3.8<\mathrm{d}<4.0 \\
\text { abr }\end{array}$ & 1384 & 361.75 & 189.5 & .52614 & 20.048 & 35.144 & $\begin{array}{l}.3021 \\
\pm 17 \\
1701\end{array}$ & $\begin{array}{l}5.516 \\
\pm 39 \\
1903\end{array}$ & $\begin{array}{l}.13245 \\
\pm \quad 48 \\
2130\end{array}$ \\
\hline B & $\mathrm{d}>4.0 ; \mathrm{abr}$ & 806.5 & 249.48 & 351.7 & .27704 & 18.666 & 21.550 & $\begin{array}{l}.3575 \\
\pm 33 \\
1970\end{array}$ & $\begin{array}{l}7.471 \\
\pm 73 \\
2169\end{array}$ & $\begin{array}{l}.15157 \\
\pm \quad 41 \\
2363\end{array}$ \\
\hline $\mathrm{C}$ & $\begin{array}{l}3.8<\mathrm{d}<4.0 \\
\text { abr }\end{array}$ & 1751 & 463.30 & 267.5 & .37187 & 18.287 & 27.113 & $\begin{array}{l}.3059 \\
\pm 22 \\
1720\end{array}$ & $\begin{array}{l}5.689 \\
\pm 43 \\
1929\end{array}$ & $\begin{array}{l}.13492 \\
\pm \quad 23 \\
2163\end{array}$ \\
\hline $\mathrm{D}$ & $\begin{array}{l}3.6<\mathrm{d}<3.8 \\
\text { abr }\end{array}$ & 1089 & 217.89 & 251.4 & .39073 & 17.486 & 30.870 & $\begin{array}{l}.2312 \\
\pm 19 \\
1340\end{array}$ & $\begin{array}{l}3.949 \\
\pm 36 \\
1623\end{array}$ & $\begin{array}{l}.12387 \\
\pm \quad 40 \\
2012\end{array}$ \\
\hline $\mathrm{E}$ & $\begin{array}{l}3.6<\mathrm{d}<4.0 \\
\text { abr }\end{array}$ & 1386 & 313.53 & 239.9 & .40977 & 18.400 & 28.735 & $\begin{array}{l}.2614 \\
\pm 18 \\
1496\end{array}$ & $\begin{array}{l}4.718 \\
\pm 35 \\
1770\end{array}$ & $\begin{array}{l}.13093 \\
\pm \quad 30 \\
2110\end{array}$ \\
\hline $\mathrm{F}$ & $\begin{array}{l}\text { titanite } \\
3.4<\mathrm{d}<3.5 \\
\text { abr }\end{array}$ & 58.11 & 21.08 & 94.2 & 1.0598 & 25.622 & 68.603 & $\begin{array}{l}.4193 \\
\pm 24 \\
2257\end{array}$ & $\begin{array}{l}6.57 \\
\pm 12 \\
2055\end{array}$ & $\begin{array}{l}.1136 \\
\pm \quad 17 \\
1858\end{array}$ \\
\hline G & $\begin{array}{l}\quad \text { titanite } \\
3.5<\mathrm{d}<3.6 \\
\text { abr }\end{array}$ & 47.17 & 17.56 & 93.0 & 1.0730 & 25.859 & 66.757 & $\begin{array}{l}.4302 \\
\pm 26 \\
2306\end{array}$ & $\begin{array}{l}6.71 \\
\pm 11 \\
2073\end{array}$ & $\begin{array}{l}.1131 \\
\pm \quad 17 \\
1850\end{array}$ \\
\hline $\mathrm{H}$ & $\begin{array}{l}\text { titanite } \\
3.4<\mathrm{d}<3.5 \\
\text { abr }\end{array}$ & 45.23 & 13.59 & 131.9 & .75374 & 21.228 & 48.724 & $\begin{array}{l}.3472 \\
\pm 19 \\
1921\end{array}$ & $\begin{array}{l}5.252 \\
\pm 55 \\
1861\end{array}$ & $\begin{array}{l}.10970 \\
\pm \quad 85 \\
1794\end{array}$ \\
\hline A2 & -Rasiaho, Saar & iekki, Kı & imo; me & abase & & & & & & \\
\hline A261A & $\begin{array}{l}4.3<d<4.6 \\
\varnothing<100\end{array}$ & 289.6 & 60.43 & 443.6 & .22203 & 15.010 & 59.151 & $\begin{array}{l}.2412 \\
\pm 17 \\
1392\end{array}$ & $\begin{array}{c}4.000 \\
\pm 48 \\
1634\end{array}$ & $\begin{array}{l}.1203 \\
\pm \quad 10 \\
1961\end{array}$ \\
\hline B & $\begin{array}{l}4.3<\mathrm{d}<4.6 \\
\varnothing>100 ; \text { abr }\end{array}$ & 274.9 & 59.61 & 429.1 & .23007 & 14.939 & 76.875 & $\begin{array}{l}.2506 \\
\pm 15 \\
1441\end{array}$ & $\begin{array}{l}4.093 \\
\pm 30 \\
1652\end{array}$ & $\begin{array}{l}.11847 \\
\pm \quad 44 \\
1933\end{array}$ \\
\hline $\mathrm{C}$ & $\begin{array}{l}4.0<\mathrm{d}<4.2 \\
\text { abr }\end{array}$ & 605.7 & 137.61 & 793.2 & .12455 & 13.612 & 63.788 & $\begin{array}{l}.2626 \\
\pm 17 \\
1503\end{array}$ & $\begin{array}{l}4.325 \\
\pm 31 \\
1698\end{array}$ & $\begin{array}{l}.11947 \\
\pm \quad 29 \\
1948\end{array}$ \\
\hline
\end{tabular}


Table 2. Continued.

\begin{tabular}{|c|c|c|c|c|c|c|c|c|c|c|}
\hline \multirow[t]{2}{*}{$\begin{array}{l}\text { Sample } \\
\text { no. }\end{array}$} & \multirow{2}{*}{$\begin{array}{c}\begin{array}{c}\text { Fraction } \\
\left(\mathrm{g} / \mathrm{cm}^{3}\right)\end{array} \\
\varnothing=\text { grain size }, \\
\mu \mathrm{m} \\
\text { abr }=\begin{array}{l}\text { grains } \\
\text { abraded }\end{array}\end{array}$} & \multicolumn{2}{|c|}{$\begin{array}{c}\text { Concentration } \\
\mu \mathrm{g} / \mathrm{g}\end{array}$} & \multirow{2}{*}{$\begin{array}{c}\frac{{ }^{206} \mathrm{~Pb}}{{ }^{204} \mathrm{~Pb}} \\
\text { measured }\end{array}$} & \multicolumn{3}{|c|}{$\begin{array}{l}\text { Isotopic composition of lead } \\
\qquad{ }^{206} \mathrm{~Pb}=100\end{array}$} & \multicolumn{3}{|c|}{$\begin{array}{l}\text { Atom ratios and radio- } \\
\text { metric ages, Ma. }\end{array}$} \\
\hline & & ${ }^{238} \mathrm{U}$ & ${ }^{206} \mathrm{~Pb}$ & & 204 & 207 & 208 & $\frac{{ }^{206 \mathrm{~Pb}}}{{ }^{238} \mathrm{U}}$ & $\frac{{ }^{20} \mathrm{~Pb}}{{ }^{235} \mathrm{U}}$ & $\frac{{ }^{207} \mathrm{~Pb}}{{ }^{206} \mathrm{~Pb}}$ \\
\hline $\mathrm{D}$ & $\begin{array}{l}4.3<d<4.6 \\
\text { abr; crushed }\end{array}$ & 286.4 & 63.07 & 432.7 & .22936 & 15.007 & 73.104 & $\begin{array}{l}.2545 \\
\pm 24 \\
1461\end{array}$ & $\begin{array}{l}4.185 \\
\pm 47 \\
1671\end{array}$ & $\begin{array}{l}.11927 \\
\pm \quad 59 \\
1945\end{array}$ \\
\hline $\mathrm{E}$ & $\begin{array}{l}4.3<\mathrm{d}<4.6 \\
\text { yellowgreen } \\
\text { abr }\end{array}$ & 270.0 & 59.68 & 1486 & .05451 & 12.269 & 28.499 & $\begin{array}{l}.2555 \\
\pm 16 \\
1466\end{array}$ & $\begin{array}{l}4.063 \\
\pm 31 \\
1646\end{array}$ & $\begin{array}{l}.11534 \\
\pm \quad 37 \\
1885\end{array}$ \\
\hline $\mathrm{F}$ & $\begin{array}{l}4.3<d<4.6 \\
\varnothing>160 ; \text { abr }\end{array}$ & 269.4 & 57.68 & 438.1 & .22192 & 14.578 & 39.825 & $\begin{array}{l}.2474 \\
\pm 21 \\
1425\end{array}$ & $\begin{array}{l}3: 953 \\
\pm 36 \\
1624\end{array}$ & $\begin{array}{l}.11586 \\
\pm \quad 30 \\
1893\end{array}$ \\
\hline G & $\begin{array}{l}4.2<\mathrm{d}<4.3 \\
\text { abr }\end{array}$ & 361.3 & 78.64 & 675.8 & .14551 & 13.906 & 73.362 & $\begin{array}{l}.2516 \\
\pm 15 \\
1446\end{array}$ & $\begin{array}{c}4.149 \\
\pm 26 \\
1664\end{array}$ & $\begin{array}{l}.11961 \\
\pm \quad 18 \\
1950\end{array}$ \\
\hline $\mathrm{H}$ & $\begin{array}{l}4.0<\mathrm{d}<4.3 \\
\text { light coloured } \\
\text { abr }\end{array}$ & 447.0 & 97.22 & 760.0 & .12353 & 13.733 & 42.568 & $\begin{array}{l}.2514 \\
\pm 53 \\
1445\end{array}$ & $\begin{array}{c}4.189 \\
\pm 89 \\
1671\end{array}$ & $\begin{array}{l}.12084 \\
\pm \quad 29 \\
1968\end{array}$ \\
\hline I & $\begin{array}{l}3.8<\mathrm{d}<4.0 \\
\text { translucent } \\
\text { abr }\end{array}$ & 1412 & 377.49 & 2178 & .04451 & 13.916 & 62.579 & $\begin{array}{l}.3090 \\
\pm 20 \\
1735\end{array}$ & $\begin{array}{c}5.679 \\
\pm \quad 37 \\
1928\end{array}$ & $\begin{array}{l}.13330 \\
\pm \quad 18 \\
2142\end{array}$ \\
\hline $\mathrm{J}$ & $\begin{array}{l}\text { titanite } \\
3.5<\mathrm{d}<3.6\end{array}$ & 22.10 & 6.99 & 108.6 & .91347 & 25.743 & 135.99 & $\begin{array}{l}.3657 \\
\pm 19 \\
2009\end{array}$ & $\begin{array}{c}6.951 \\
\pm 49 \\
2105\end{array}$ & $\begin{array}{l}.13784 \\
\pm \quad 55 \\
2200\end{array}$ \\
\hline K & $\begin{array}{l}\text { titanite } \\
3.5<\mathrm{d}<3.6 \\
\text { abr }\end{array}$ & 20.07 & 6.85 & 150.7 & .65514 & 22.325 & 137.18 & $\begin{array}{l}.3947 \\
\pm 31 \\
2144\end{array}$ & $\begin{array}{c}7.479 \\
\pm 69 \\
2170\end{array}$ & $\begin{array}{l}.13744 \\
\pm \quad 52 \\
2195\end{array}$ \\
\hline $\mathrm{L}$ & $\begin{array}{l}3.8<\mathrm{d}<4.0 \\
\text { translucent } \\
\varnothing>70 ; \text { abr }\end{array}$ & 1298 & 352.95 & 2122 & .04473 & 13.711 & 73.093 & $\begin{array}{l}.3142 \\
\pm 18 \\
1761\end{array}$ & $\begin{array}{c}5.683 \\
\pm 33 \\
1928\end{array}$ & $\begin{array}{l}.13121 \\
\pm \quad 10 \\
2114\end{array}$ \\
\hline
\end{tabular}

\section{References}

Arndt, N.T. and Jenner, G.A., 1986. Crustally contaminated Komatiites and Basalts from Kambalda, Western Australia. Chemical Geol.,56, 229-255.

Carter, R.M. \& Norris, R.J., 1976. Cainozoic history of southern New Zealand: an accord between geological observations and plate-tectonic predictions. Earth Planet. Sci. Letts, 31, 85-94.

Condie, K.C., 1985. Secular Variation in the Composition of Basalts: an Index to Mantle Evolution. J. of Petrol., vol.26, Part 3,545-546.

Eskola, P.E., 1919. Huvuddragen av Onega-Karelens geologi. Teknikern, 1919, 37-39.

—, 1941. Erkki Mikkola und der heutige stand der präkambrischen Geologie in Finland. Geologishe Rundschau Bd. 32. Heft 4/5.
—, 1963. The Precambrian of Finland. In: K. Rankama (Ed) The Precambrian, vol. 1, John Wiley \& Sons Inc. New York-London-Sydney.

Fowler, A.D., Jensen, L.S. and Peloquin, S.A., 1987. Variolites in Archaean basalts: products of spherulitic crystallization. Canadian Mineralogist. Vol. 25, 275-289.

Gill, J.B., 1981. Orogenic andesites and plate tectonics. Springer-Verlag, New York. 390 p.

Harding, T.P., 1985. Seismic Characteristics and Identification of Negative Flower Structures, Positive Flower Structures, and Positive Structural Inversion. Am. Ass. Petrol. Geol. Bull., vol. 69, No 4. 582-600.

Hempton, M.R., Dunne, L.A. and Dewey, J.F., 1983. Sedimentation in an active strike-slip basin, southeastern Turkey. J. Geology, 91, 401-412.

Huppert, H.E., Sparks, R.S.J., Turner, J.S. and Arndt, N.T., 1984. Emplacement and cooling of Komatiite lava. Na- 
ture (London), 309, 19-22.

—, \& Sparks, R.S.J., 1985. Cooling and contamination of mafic and ultramafic lavas during ascent through continental crust. Earth Planet. Sci. Lett.,74, 371-386.

-, 1988. The Generation of Granitic Magmas by Intrusion of Basalt into Continental Crust. J. of Petrol., vol.29, Part 3, 599-624.

Hyppönen, V., 1983. Kallioperäkarttojen selitykset, 4411 Ontojoki, 4412 Hiisijärvi ja 4413 Kuhmo. English summary: Pre-Qarternary rocks of the Ontojoki, Hiisijärvi and Kuhmo map sheet areas. Geological map of Finland 1: 100 000. Espoo: Geological Survey of Finland. 60p.

Irvine, T.N. and Baragar, W.R.A., 1971. A guide to the chemical classification of the common volcanic rocks. Can. J. Earth Sci., 8. 523-548.

Jaffey, A.H., Flynn, K.F., Glendenin, L.E., Bentley, W.C. \& Essling, A., 1971. Precision measurement of half-lives and specific activities of ${ }^{235} \mathrm{U}$ and ${ }^{238} \mathrm{U}$. Phys. Rev C4, 1889-1906.

Jensen, L.S., 1976. A new cation plot for classifying subalkalic volcanic rocks. Ont. Dep. Min. Misc. Pap. 66, 22 p.

Kratz, K.O., 1976. Age range of the Jatulian Complex of Karelia. Dokl. Acad. Nauk. SSSR, Earth Sci, Sect, 231, (5), 1191-1194.

— \& Mitrofanov, F., 1980. Main type reference sequences of the early Precambrian in the U.S.S.R. Earth Sci Review. 16. 295-301.

Kilpelä, M., 1990. Karttalehtien 4421, 4423+4441 alueen metadiabaaseista. Pro gradu -tutkielma. Geologian ja mineralogian laitos, Turun yliopisto. in preparation.

Kulikov, V.S. \& Golubev, A.I., 1984. The Sumian-Sariolan. In: V.A.Sokolov (ed.) GUIDE-BOOK Geological field trips in Karelia. Institute of Geology Academy of Sciences of the USSR Karelian Branch. Petrozavodsk 1984. $15-18$.

Laajoki, K., 1973. On the geology of the South Puolanka area, Finland. Geol. Surv. Finland, Bull. 263. 54 p.

-, 1980. Outlines of the Precambrian geology of the North Puolanka area, Finland. Res Terrae, Ser. A. 1. 11p.

Luukkonen, E.J., 1985. Structural and U-Pb isotopic study of late Archaean migmatitic gneisses of the Presvecokarelides, Lylyvaara, eastern Finland. Trans. R. Soc. Edinburgh Earth Sci. 76, 401-410.

- , 1988a. The structure and stratigraphy of the northern part of late Archaean Kuhmo greenstone belt, eastern Finland. In E. Marttila (ed.) Archaean geology of the Fennoscandian Shield, 71-96. Geol. Surv. Finland, Spec. Paper 4.

—, 1988b. Kallioperäkarttojen selitykset, 4421 Moisiovaara ja Ala-Vuokki. English summary: Pre-Quarternary rocks of the Moisiovaara and Ala-Vuokki map sheet areas. Geological map of Finland 1: 100 000. Espoo, Geological Survey of Finland.

- \& Lukkarinen, H., 1986. Explanation to the stratigraphic map of Middle Finland. Geol. Surv. Finland Rep. Inv.
$74,47 \mathrm{p}$.

Marmo, J.S., 1986. Sariolan stratigraphy and sedimentation in the Koli-Kaltimo area, North Karelia, eastern Finland. In V. Sokolov (ed.) Proceedings of Symposium on the lower Proterozoic formations on the eastern part of the Baltic Shield, Petrozavodsk, 1985.

Marmo, J.S. \& Ojakangas, R. W., 1983. Varhaisproterosooinen Urkkavaara-muodostuma Kontiolahdella; glasigeeninen metasedimenttisarja sariolaryhmän yläosassa. Summary: Early Proterozoic Urkkavaara Formation in Kontiolahti, North Karelia - A glacigenic metasedimentary sequence in the upper Sariolan group. Geologi 35, 27-29.

-, 1984. Lower Proterozoic glaciogenic deposits, eastern Finland. Geol.Soc.Am.Bull.95, 1055-1062.

-; Kohonen, J., Sarapää, O. \& Aikäs, O., 1988. Sedimentology and stratigraphy of the lower Proterozoic Sariola and Jatuli Groups in the Koli-Kaltimo area, eastern Finland. In: K.Laajoki and J.Paakkola (eds) Sedimentology of the Precambrian formations in eastern and northern Finland. Geol. Surv. Finl. Spec. Paper 5. 11-28.

Meriläinen, K., 1980. On the stratigraphy of the Karelian formations. In A. Silvennoinen (ed.) Jatulian geology in the eastern part of the Baltic Shield. Proceedings of a FinnishSoviet Symposium, Finland, 1979, 9-12. See also Stratigraphy of the Precambrian in Finland. Geol.Fören. Stockholm Förh. 102(2), 177-180.

Nardin, T.R. \& Henyey, T.L., 1978. Pliocene-Pleistocene diastrophism of Santa Monica and San Pedro shelves, California continental Borderland. Bull.Am.Ass.Petrol.Geol. 62, 247-272.

Nesbitt, H.W. \& Young, G.M., 1982. Early Proterozoic climates and plate motions inferred from major element chemistry of lutites. Nature, vol.299, No. 5885, 715-717.

Norris, RJ., Carter, R.M. \& Turnbull, I.M., 1978. Cainozoic sedimentation in basins adjacent to a major continental transform boundary in southern New Zealand. J.geol. Soc.Lond.135, 191-205.

Ojakangas, R.W., 1965. Petrography and sedimentation of the Precambrian Jatulian quartzites of Finland. Bull.Comm.geól. Finlande 214, 74p.

Park, A.F., Bowes, D.R., Halden, N.M. \& Koistinen, T.J., 1985. Tectonic evolution at an early Proterozoic continental margin: the Svecokarelides of eastern Finland. J. Geodynamics 1, 359-386.

Paerce, J.A., 1983. Role of the Sub-continental Lithosphere in Magma Genesis at Active Continental Margins. In: C.J.Hawkesworth and M.J.Norry (Eds.), Continental Basalts and Mantle Xenoliths. Shiva Press, Nantwich, 230-249.

Pekkarinen, L.J., 1979. The Karelian formations and their depositional basement in the Kiihtelysvaara - Värtsilä area, East Finland. Geol.Surv.Finland,Bull. 301, 141p.

Pettijohn, F.J., 1975. Sedimentary Rocks. Harber \& Row, Publishers, New York-Evanston-San Francisco-London. 
$628 \mathrm{p}$

Ramsay, J.G. and Huber, M.I., 1987. The Techniques of Modern Structural Geology, vol. 2: Folds and Fractures. Academic Press; Harcourt Brace Jovanovich, Publishers, $699 \mathrm{p}$.

Reading, H,G., 1980. Characteristics and recognition of strike-slip fault systems. Spec. Publ. int. Ass. Sediment.4, $7-26$.

Sokolov, V.A. \& Stenar, N.M., 1980. Prinzipy ia i korrelatzyi dokekambrija jugo-vostoshnoi chasti Baltijkogo skita. Prinzipy i kriteri dokembrija v mobilńykh zonakh, Leningrad (with English and French abstracts).

Strand, K., 1985. Alaproterosooisen Kurkikylän ryhmän ja sen päällä olevien karjalaisten muodostumien litostratigrafia, paleosedimentologia ja rakenne. Res Terrae Ser. B 7. $140 \mathrm{p}$.

-, 1988. Alluvial sedimentation and tectonic setting of the early Proterozoic Kurkikylä and Kainuu Groups in northern Finland. In: Laajoki,K. and Paakkola,J. (eds) Sedimentalogy of the Precambrian formations in eastern and northern Finland. Geol. Spec. Paper 5. 75-90.

Sylvester, A.G., 1988. Strike-slip faults. Geol. Soc. Am. Bull. v.100. 1666-703.

Taylor, S.R. \& McLennan, S.M., 1981. The composition and evolution of the continental crust: rare earth evidence from sedimentary rocks. Philos. Trans. R. Soc. London, ser. A, 301. 381-399.

Thompson, R.N., Morrison, M.A., Dickin, A.P. \& Hendry, G.L., 1983. Continental Flood Basalts Arachnids Rule OK ? In: C.J. Hawkesworth and M.J.Norry (Eds.), Continental Basalts and Mantle Xenoliths. Shiva Press, Nantwich, 158-185.

Viljoen, R.P. \& Viljoen, M.J., 1982. Komatiites: a historical review. In N.T. Arndt and E.G.Nisbett (eds), Komatiites, George Allen and Unwin, London, 5-18.

Väyrynen, H., 1933. Über die Stratigrafie der karelischen Formationen. Bull. Comm. geól. Finlande 101, 54-78.

-, 1954. Suomen kallioperä, sen synty ja geologinen kehitys. Otava, Helsinki. 260p.

Wilkman, W.W., 1921. Vuorilajikartan selitys D 4, Nurmes. $126 \mathrm{p}$.

Zhuravlev, V.A., Ivanov, N.M., Negrutza, V.Z., Negrutza, T.F. \& Pushkin, G.J., 1979. Prejatulian formations of the link zone between Karelides and Belomorides. In A. Silvennoinen (ed.) Jatulian geology in the eastern part of the Baltic Shield. Proceedings of a Finnish-Soviet Symposium, Finland, 1979, 239-251.

Received August 18, 1989

Revision accepted October 27, 1989 